\title{
Próun hönnunarhugsunar og beiting hennar innan íslenskra fyrirtækja og stjórnsýslu
}

\author{
Ingibjörg Rafnar Pétursdóttir og Magnús Pór Torfason ${ }^{1}$
}

\begin{abstract}
Ágrip
Á síðustu árum hefur færst í vöxt að beitt sé aðferðafræði sem kennd er við hönnunarhugsun (e. design thinking) í próunarverkefnum, bæði á vegum hins opinbera og í einkageiranum. Í pessari grein er kannað hvernig hönnunarhugsun er beitt við mismunandi aðstæður innan íslenskrar stjórnsýslu og fyrirtækja. Fram kemur í viðtölum að hönnunarhugsun er talin styðja við samtal milli mismunandi hagsmunaaðila og valdeflingu peirra, auk pess sem viðmælendur telja aðferðina gagnlega við að takast á við pá óvissu sem fylgir nýsköpunarverkefnum. Aftur á móti skynja viðmælendur ákveðna togstreitu á milli pess hvernig mismunandi aðilar nálgast hönnunarhugsun. Höfundar setja fram kenningu um að pessi togstreita markist að hluta til af sögulegri próun hönnunarhugsunar og premur bylgjum sem mótað hafa áherslur aðferðafræðinnar í gegnum tíðina. Fyrsta bylgjan markast af náinni tengingu við iðnhönnun og aðferðir hönnuða. Önnur bylgjan einkennist af áherslu á nýsköpun og ferlavæðingu hönnunarhugsunar. Í priðju bylgjunni er sjálfbærni og samkeppnishæfni samfélaga í forgrunni og athyglinni beint í auknum mæli að notkun hönnunarhugsunar í opinberri stjórnsýslu. Ákveðin samsvörun er milli peirra meginpema sem koma fram í viðtölunum og pessara priggja bylgja, og kann sú nálgun sem sett er fram hér að hjálpa til við að skýra og skilja mismunandi viðhorf til aðferðarinnar, bæði hér á landi og alpjóðlega. Pessar niðurstöður eru mikilvægar í ljósi pess að mikilvægi hönnunar eykst stöðugt og alpjóðastofnanir á borð við Evrópusambandið leggja sívaxandi áherslu á hönnun og hönnunarhugsun.
\end{abstract}

\section{Abstract}

In recent years, design thinking methods have increasingly been used in development projects, both in the public and private sectors. This study explores how design thinking is used in different contexts within Icelandic administration and corporations. Qualitative interviews suggest that design thinking is seen as an empowering methodology that supports the conversation between different stakeholders, and that it is effective at managing the inherent uncertainty of innovative projects. On the other hand, the correspondents sense a certain tension between how different people approach design thinking. The authors theorize that this tension may in part originate in the history of design thinking, which has evolved through three distinct waves. The first wave is characterized by a close relationship with design methods and industrial design. The second wave is denoted by an

1 Ingibjörg Rafnar Pétursdóttir er verkefnastjóri hjá Össuri hf. Netfang: imbarafnar@gmail.com. Magnús Pór Torfason er lektor við Viðskiptafræðideild Háskóla Íslands. Netfang: torfason@hi.is..

This work is licensed under a Creative Commons Attribution 4.0 License.

DOI: https://doi.org/10.24122/tve.a.2019.16.1.1 
emphasis on innovation and introduction of formal processes in design thinking. In the third wave, sustainability and the sustainable advantage of nations is in the foreground, with an increasing emphasis on the use of design thinking in public administration. The main themes uncovered in the interviews reflect these waves to some extent, and the theoretical approach suggested here may help understand different perspectives towards design thinking, both in Iceland and internationally. The results are important in light of the growing importance of design methods and because international organizations such as the European Union increasingly emphasize the use of design and design thinking.

JEL flokkun: M10

Lykilorð: Hönnunarhugsun; Hönnun; Nýsköpun; Sjálfbærni.

Keywords: Design thinking; Design; Innovation; Sustainability.

\section{Evolution of Design Thinking and its use in Public and Private Org- anizations in Iceland.}

\section{Inngangur}

Atvinnuumhverfi dagsins í dag einkennist af fjölbreytni, hraðri tæknipróun og kröfu um sveigjanleika í próun á vörum og pjónustu. Aðferðum „hönnunarhugsunar“ (e. Design Thinking) hefur verið teflt fram sem mögulegri lausn fyrir fyrirtæki og stofnanir til að bregðast á uppbyggilegan máta við peim breytingum sem eru að eiga sér stað í starfsumhverfi peirra (Brown, 2009; Kelley, 2016). Pótt hugtakið „hönnun“ hafi upphaflega aðallega verið tengt við við útlit eða stílfærslu á vörum og pjónustu er merking pess orðin mun víðtækari en pað. Pví hefur jafnvel verið haldið fram að í raun hafi allt sem ekki er hluti náttúrunnar eða afurð hennar verið „hannað“ á einn eða annan máta (Cross, 2011).

Ekki liggur fyrir ein almenn skilgreining á pví hvað enska hugtakið „Design Thinking“ felur í sér (Rieple, 2016; van Reine, 2017), pótt pað sé mikið notað. Rekja má aðferðafræði hönnunarhugsunar aftur til loka sjöunda áratugar síðustu aldar (Huppatz, 2015) en með árunum hefur notkun aðferðarinnar breiðst út og henni hefur verið beitt á fjölbreyttari vandamál. Í grundvallaratriðum er hönnunarhugsun aðferðafræði sem byggir á samvinnu og notendamiðaðri nálgun (e. human-centered approach) við lausnapróun, par sem áhersla er lögð á virka skoðun og athuganir, samstarf, hraðan lærdóm og ítranir (e. iterations), skjóta vinnslu frumgerða og heildstæða greiningu á viðskiptaumhverfinu (Brown, 2009). Markmið aðferðarinnar getur verið að auka nýsköpun eða vinna stefnumótun fyrir stjórnsýslustofnanir, fyrirtæki og aðrar skipulagsheildir og er hún talin nýtast í verkefnum á breiðum grunni, s.s. vörupróun, pjónustupróun, endurskoðun heildarskipulags fyrirtækja og allt par á milli (Lockwood, 2010).

Talsverð vakning hefur átt sér stað á síðustu árum innan íslenskrar stjórnsýslu um mikilvægi pess að brúa bilið milli sköpunargáfu og nýsköpunar og í pví samhengi hafa aðferðir hönnunar verið nefndar sem mikilvægur drifkraftur til aukinnar verðmætasköpunar (Atvinnuvega- og nýsköpunarráðuneyti og Mennta- og menningarmálaráðuneyti, 2014). Próunin er enn meira áberandi á vettvangi Evrópu, en Evrópusambandið hefur á síðustu árum lagt ríka áherslu á að fyrirtæki og stofnanir kynni sér möguleika á nýtingu hönnunarhugsunar, eins og kemur fram í aðgerðaráætlununum Design for Growth and Prosperity (Framkvæmdastjórn Evrópusambandsins, 2012) og Design for Innovation (Framkvæmdastjórn Evrópusambandsins, 2013). Afstaða sambandsins er að Evrópulönd purfi að styrkja nýsköpunarstarfsemi sína par sem tæknilegt forskot peirra fari sífellt minnkandi í samkeppninni á heimsmarkaði og er vísað til hönnunarmiðaðrar nýsköpunar sem mótsvars við aðkallandi pörf fyrir efnahagslegan vöxt og fjölgun starfa í Evrópu (Framkvæmdastjórn Evrópusambandsins, 2012, 2013, 2016). Pví er fyrirséð að hönnunarhugsun 
verði æ ríkari páttur í nýsköpun innan stjórnsýslunnar og mikilvægt að auka skilning á aðferðafræðinni bæði meðal almennings og innan fræðasamfélagsins. Sú rannsóknarspurning sem er undirliggjandi í pessari rannsókn er eftirfarandi:

Hvernig er hönnunarhugsun beitt við mismunandi aðstæður á Íslandi, og hvernig fellur beiting aðferðarinnar á Íslandi að straumum og stefnum á alpjóðlegum vettvangi.

Til að leita svara við pessari rannsóknarspurningu er sett fram greining á fjórtán viðtölum við einstaklinga sem beitt hafa aðferðum hönnunar í fjölbreyttum verkefnum á Íslandi, bæði innan opinbera geirans og einkageirans. Við rannsóknina komu fram vísbendingar um að í próun hönnunarhugsunar mæetti greina prjú megintímabil, eða bylgjur, sem varpað gætu nánara ljósi a fjölbreytta nálgun og í sumum tilvikum togstreitu við beitingu aðferðafræðinnar. Pví voru heimildir um hönnunarhugsun greindar myndrænt út frá pessum mögulegu bylgjum, og sú greining síðan tvinnuð saman við greininguna á viðtölunum.

I kaflanum hér á eftir er fjallað stuttlega um aðferðafræðina sjálfa og beitingu hennar í mismunandi verkefnum. Annar kafli er fræðilegt yfirlit par sem athyglinni er beint að fyrri rannsóknum á hönnunarhugsun og hvernig hönnunarhugsun hefur próast frá pví að hún kom fyrst fram. Í priðja og fjórða kafla er fjallað um aðferðafræði og niðurstöður pemagreiningar á viðtölum við aðila sem hafa beitt hönnunarhugsun við verkefni á Íslandi og myndrænnar greiningar á heimildum. Umræður og lokaorð er að finna í fimmta kafla, sem hnýtir saman pemagreiningu viðtalanna og greiningu heimildanna út frá bylgjunum prem.

\section{Aðferðir hönnunarhugsunar}

Hönnunarhugsun - sem aðferð og hugmyndafræði - hefur próast töluvert frá pví að hún kom fyrst fram. Pví er eðli málsins ekki hægt að setja fram eina aðferð sem endanlegan málsvara fyrir hugmyndafræðina, en pó er mikilvægt að fjalla stuttlega um helstu pætti sem einkenna verkefni byggð á hönnunarhugsun. Umfjölluninni er ekki ætlað að vera tæmandi lýsing á aðferðum hönnunarhugsunar heldur er hún hugsuð til pess að veita aukna innsýn í hvaða áherslur felast í aðferðum hönnunarhugsunar og hugmyndaheiminum par að baki. Ferlavæðing hönnunarhugsunar hefur oft verið kennd við hönnunarfyrirtækið IDEO og hugmyndasmiði pess, David og Tom Kelley (sbr. Brown, 2009; Dam og Siang, 2017; Liedtka, Salzman og Azer, 2017; Rieple, 2016), og pví er viðeigandi að byggja slíkt yfirlit á útfærslu úr peirra smiðju.

Samkvæmt peirri útfærslu sem sett var fram af Kelley (2016), má skipta verkefnum gróflega í fimm pætti sem eru eftirfarandi: hluttekning (e. empathy), afmörkun (e. definition), hugmyndun (e. ideation), próun frumgerða (e. prototyping), og prófanir (e. testing). Yfirlit yfir pennan feril má sjá á mynd 1, par sem einnig kemur fram að pótt pættirnir séu y firleitt unnir lauslega í tímaröð er mikilvægur eiginleiki hönnunarhugsunar að verkefnavinnan sé sveigjanleg og pví er mögulegt að verkefnið færist fram og til baka milli ólíkra pátta.

Fyrsti fasinn, hluttekning, snýr að pví að lögð er áhersla á að fá dýpri innsýn í vandamálið eða viðfangsefnið sem er til skoðunar. Petta getur falið í sér að ráðfæra sig við sérfræðinga á sviðinu; skoða hvernig notendur eða viðskiptavinir upplifa núverandi lausnir og hverjar parfir peirra eru, og er markmiðið að tryggja að verkið sé unnið sem mest út frá sjónarhorni og hugarheimi notandans en ekki pess sem vinnur að próunarverkefninu.

Í kjölfar hluttekningar sem veitir víða innsýn er verkefnið afmarkað út frá greiningu á peim upplýsingum sem par komu fram. Á pessu stigi eru grundvallarspurningar oft skilgreindar sem hjálpa verkefninu áfram á síðari stigum og tilraun gerð til að skilja hvernig lausnin kemur notendum fyrir sjónir. Skoðað er hvernig notendur umgangast lausnina og hvort mögulegt sé að einfalda notkunarmynstur viðskiptavina. 
Næsti fasi einkennist af hugmyndavinnu eða hugmyndun, par sem viðfangsefnið er skoðað út frá ólíkum áttum og leitast við að „hugsa út fyrir boxið“ til pess að kanna nýjar lausnir. Margar ólíkar aðferðir eru notaðar á pessu stigi, m.a. hugarflæði sem byggir á virku opnu samtali par sem ákveðið skipulag er haft að leiðarljósi til pess að tryggja virkt flæði hugmynda. Áhersla er lögð á heildræna skilgreiningu á pví vandamáli sem er til úrlausnar hverju sinni, að viðhalda leik í samtalinu, og á myndræna nálgun í umræðum.

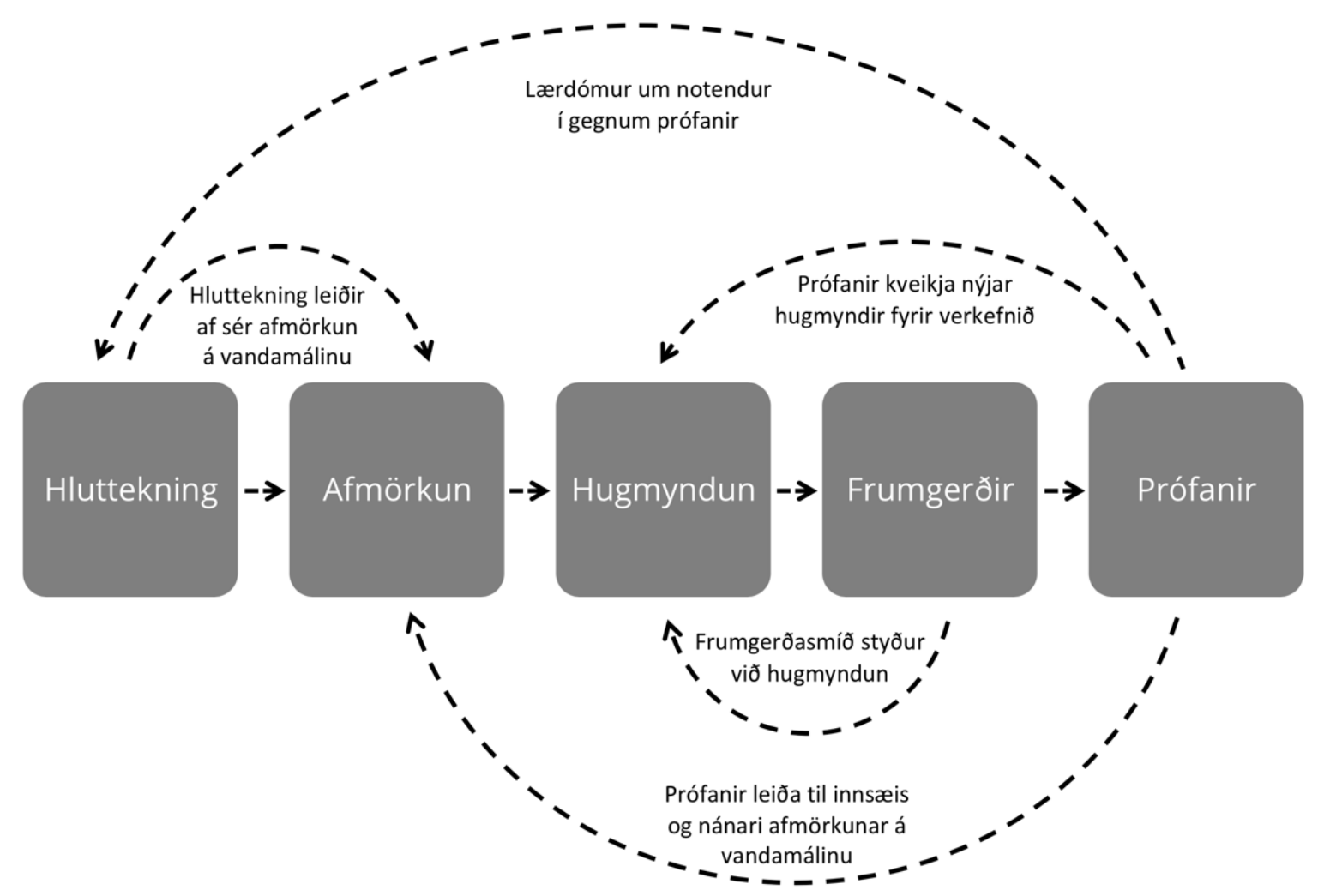

Mynd 1. Ólínulegt próunarferli hönnunarhugsunar samkvæmt aðferðafræði IDEO, (Byggt á myndrænni framsetningu Dam og Siang (2017) á útfærslu Kelley (2016))

Strax í kjölfarið eru próaðar frumgerðir par sem teymin vinna ódýrar og fljótlegar útfærslur á mögulegum lausnum til prófunar fyrir áframhaldandi próun. Pessar frumgerðir geta verið í skissuformi, grófar eftirlíkingar par sem jafnvel eru notaðir hlutir sem eru til á skrifstofunni (pennar, stimplar, heftarar eða annað sem hendi er næst), söguspjöld (e. storyboards) eða hlutverkaleikir (Brown, 2009). Vinnsla frumgerðanna er talin vera ákveðið lærdómsferli út af fyrir sig og vísað er til vinnslu frumgerða sem leiðar til pess að „mistakast hratt“ (e. fail fast) og geta pá fært sig yfir í aðrar lausnir sem geta gefið betri árangur.

pessar frumgerðir fara jafnóðum í gegnum prófanir par sem fer fram virkt samtal við notendur sem fengnir eru til að nota frumgerðina og segja frá upplifun sinni til pess að fá betri hugmynd um hvort lausnapróunin sé á réttri leið. Enn eru gerðar breytingar á lausninni í samræmi við upplýsingar úr prófununum og pannig færist ferlið aftur í fyrri fasa par til endanleg lausn er komin á markað.

Ferillinn er ekki fastmótaður og getur tekið á sig ýmsar myndir og verið settur fram í fleiri eða færri skrefum en peim fimm sem talin eru upp hér að ofan. Nánast allar slíkar nálganir eiga pó sammerkt að leggja áherslu á pessa meginpætti, auk pess sem talið er mikilvægt að byggja á nánu og virku teymissamstarfi, og leggja áhersla á samsetningu teyma með tilliti til bakgrunns, persónugerða og annarra pátta. 


\section{Próun hönnunarhugsunar}

Á síðustu áratugum hefur aðferðum hönnunarhugsunar verið beitt á breiðari grundvelli innan fyrirtækja og stofnana. Aðferðinni hefur verið beitt við fjölmarga pætti, allt frá hugmyndaflæði um mögulegar lausnir, vinnslu frumgerða, framleiðslu á lausnum, skipulag starfsheilda, samskipti við viðskiptavini, markaðssetningu og vörumerkjapróun með fyrrnefndar meginstoðir aðferðarinnar að leiðarljósi (Kelley, 2005; Brown, 2009; Martin, 2009). Rannsóknir sýna að innleiðing hönnunarhugsunar í heildarskipulagi fyrirtækja og stofnana felur í sér víðtækari breytingar en að setja upp grunnferla og veita starfsfólki pau áhöld sem til parf (van Reine, 2017; Martin, 2009; Lockwood, 2010; Kelley, 2005). Stöðugt bætist við pekkinguna um pá pætti sem nauðsynlegir eru til að notkun hönnunarhugsunar skili árangri, enda hefur pessi aðferðafræði próast mikið á undanförnum áratugum.

\subsection{Upphafið: Hönnun beitt í víðara samhengi}

Hönnunarhugsun grundvallaðist upphaflega á rannsóknaraðferðum hönnunar, p.e. hvernig hönnuðir nálgast viðfangsefni sitt, taka ákvarðanir um næstu skref og leita lausna fyrir viðfangsefni sitt (Wilcox, 2016), en nýnæmi aðferðarinnar fólst í pví að nýta pessar aðferðir á víðtækari máta en áður (Cooper, Junginger og Lockwood, 2010). Áður hafði aðkoma hönnuða innan atvinnulífsins verið takmörkuð við afmörkuð verkefni tengd vörupróun en á sjöunda og áttunda áratugnum voru settar fram kenningar um hlutverk hönnunar við lausn flókinna áskorana (Simon, 1969), sem höfðu töluverð áhrif á mótun aðferðanna að baki hönnunarhugsunar (Huppatz, 2015). Hugmyndir Simon voru svo settar í samhengi við hugmyndina um illviðráðanleg vandamál (e. wicked problems). Hugtakið vísar til flókinna vandamála sem erfitt er að skilgreina og henda reiður á. Pessi illviðráðanlegu vandamál einkennast af pví að vera langvarandi, útbreidd, kerfisbundin og óápreifanleg, auk pess sem pau eru innbyrðis ólík (Rittel og Webber, 1973), og pví til mikils unnið ef hægt væri að nýta reynslu iðnhönnuða til að takast á við slíkar áskoranir í viðskipta- og atvinnulífinu.

Illviðráðanleg vandamál í skilningi Rittel og Webber breytast pegar tilraun er gerð til pess að leysa pau og samkvæmt kenningum peirra er í raun ekki hægt að finna eina einstaka lausn á peim. Eðli málsins samkvæmt kalla slík vandamál á aðkomu margra aðila og ríkara samtal á milli hönnuðar og peirra aðila sem leita lausnar á vandamálinu (Buchanan, 1992), og má segja að sá páttur sem snýr að notendamiðuðum áherslum hönnunarhugsunar spretti upp úr peirri hugmyndafræði. Pessi próun byggði á hugmyndum um að styrkleikinn í aðferðum hönnuða væri getan til pess að nálgast viðfangsefnið á mjög opinn og fjölpættan máta.

A upphafsdögum hönnunarhugsunar voru hönnuðir og tengdir aðilar í leiðandi hlutverki og byggði hugmyndafræðin á peim tíma aðallega á pví að nýta getu og reynslu iðnhönnuða til að leysa fleiri vandamál en peir höfðu áđur tekist á við, frekar en að um væri að ræða aðferðafræði sem aðrir gætu tileinkað sér á einfaldan máta. Dæmi um pessa nálgun er rannsókn Lawson (1983) á aðferðum arkitekta par sem hann skoðaði sérstaklega hlutverk teikninga og skissugerðar í skapandi vinnsluferli peirra. Lawson hélt pví fram að vinnsluferlið væri í raun lærdómsferli par sem í upphafi verkefna lægju ekki allar upplýsingar fyrir heldur kæmu ólíkar hliðar vandamálsins í ljós pegar lausnapróun hæfist. Í pessu ferli sé pví ávallt fólgin óvissa um endanlega niðurstöðu verkefna og taldi Lawson að styrkleikar hönnuða fælust í hæfileikanum til að takast á við petta óvissuástand, nálgast viðfangsefnið út frá óskyldum sjónarmiðum og sameina í einni lausn.

Á bak við hugmyndir um að nýta iðnhönnuði við lausn illviðráðanlegra vandamála er pví sú hugsun að nálgun hönnuða sé eðlisólík nálgun annarra við lausn vandamála. Dorst (2011) telur til dæmis að hugsanaferli hönnuða sé í eðli sínu ólíkt pví sem tíðkast innan annarra starfsgreina og аð önnur svið atvinnulífsins eigi erfitt með að tileinka sér pað. Engu að síður skapi pessi ólíka nálgun hönnuða í hugmyndapróun og ákvarðanatöku 
ákveðnar áskoranir, og pví sé mjög mikilvægt að leggja áherslu á öflug og uppbyggileg samskipti við pá aðila innan fyrirtækja sem vanir eru að vinna samkvæmt öðrum forsendum (Rieple, 2016). Petta hefur einnig áhrif á innleiðingu hönnunarhugsunar í fyrirtækjum á breiðara sviði par sem ferlar innan fyrirtækja eru byggðir á hefðbundnari starfsaðferðum sem byggja meira á línulegri nálgun og ekki er hefð fyrir jafnopinni nálgun á viðfangsefnið (van Reine, 2017).

\subsection{Hönnunarhugsun festist í sessi}

Með aukinni meðvitund um ávinning hönnunar utan pröngs sviðs vöruhönnunar jókst áhersla á notkun hönnunarhugsunar í tengslum við nýsköpun og stefnumótun fyrirtækja (Berkowitz, 1987; Kotler og Rath, 1984; Roy, 1993). Samhliða pví varð smám saman ákveðin umbreyting á pví hvernig rannsakendur og aðilar innan atvinnulífsins sáu hlutverk hönnunarhugsunar. Í stað pess að hönnunarhugsun snerist um að menntaðir iðnhönnuðir tækju pátt í lausn nýrra verkefna sá fólk tækifæri til pess að einstaklingar sem ekki höfðu hönnunarbakgrunn tileinkuðu sér aðferðir hönnunarhugsunar. Sem dæmi má nefna rannsóknir Bucciarelli's $(1988,1994)$ á vinnulagi verkfræðinga sem sýndu að aðferðir verkfræðinga í hönnun væru ekki einvörðungu tæknilegs eðlis heldur væri einnig ríkur félagslegur páttur í vinnsluaðferðunum sem byggðust á opnum vinnurýmum, sýnileika verkefna og virku samtali við samstarfsfólk um lausnapróun í gegnum vinnsluferlið. Um svipað leyti settu Peter Rowe og aðrir fram hugmyndir sínar um að ávinningur hönnunarhugsunar fælist í pví að aðferðin gerði kleift að nálgast verkefni á kerfisbundinn hátt með pví að brjóta hugmyndapróun upp í ólíka fasa og greina vandamálin sem eru til skoðunar niður í smærri einingar og sameina síðan í einni heildstæðri lausn (Cross, 2011).

Pessa nýju nálgun má sjá einna sterkast í hönnunarfyrirtækinu IDEO sem hefur allt frá stofnun haft mikil áhrif á notkun og mótun hönnunarhugsunar. Par var lögð áhersla á pverfaglega nálgun í hönnun byggða á skapandi hugarfari og peirri verkfærakistu sem hönnuðir höfðu áður nýtt pess að takast á við margbreytileg verkefni. Pessi nálgun markaði ákveðin tímamót, pví ekki hafði áður verið gerð jafnskýr tenging milli aðferða hönnunar og nýsköpunar. Framsetning IDEO á hönnunarhugsun í nokkurskonar ferli höfðaði vel til atvinnulífsins og fyrirtæki hófu innleiðingu á aðferðunum í starfsemi sinni í mun ríkari mæli en áður hafði verið. Fyrirtæki fóru ýmist pá leið að nýta sér ráðgjöf hönnunarfyrirtækja við innleiðingu á aðferðum hönnunarhugsunar í starfseminni eða komu á fót sérstökum hönnunardeildum (e. design centers) sem aðlöguðu ferlana að fyrirtækinu og pörfum pess í nýsköpun og próun (van Reine, 2017).

Beiting hönnunarhugsunar í nýsköpunarferlinu skapar tækifæri til að takast á við pá togstreitu sem óhjákvæmileg er milli rannsókna (e. exploration) og hagnýtingar (e. exploitation) í starfsemi fyrirtækja (Brown, 2009). Nálgun Martin (2009) gagnvart pessari áskorun er að líta á nýsköpunarferlið sem pekkingartrekt (e. knowledge funnel). Pekkingartrektin byggir á pví að sameina pá greiningarhugsun (e. analytical thinking) sem undirbyggir hugsunarhátt hagnýtingarfyrirtækja við pá innsæishugsun (e. intutition thinking) sem einkennir ákvarðanatöku innan nýsköpunarfyrirtækja. Fremst í pessari trekt er áherslan lögð á óvissu eða dulúð (e. mystery). İ kjölfarið er lagt upp í leitarferli (e. heuristic), par sem óvissunni er smám saman eytt. Pegar búið er að eyða óvissunni stendur eftir skýrt afmarkað ferli eða algrím (e. algorithm) sem er pá lausnin á upphaflega vandanum. Pessi hugsun Martin er ekki ósvipuð fimm prepa ferli IDEO í hönnunarhugsun, og ýmsar aðrar útfærslur eru til.

Samhliða auknum vinsældum hönnunarhugsunar og peirri auknu ferlavæðingu sem gerði fleiri aðilum kleift að beita aðferðinni komu fram vandamál og ný togstreita. Til dæmis voru menntaðir hönnuðir ósáttir við að aðferðir hönnunar væru settar fram sem staðlaðir ferlar og í raun væri hönnunarhugsun nú keyrð áfram innan atvinnulífsins af öðrum en hönnunarsamfélaginu (Walters, 2011). Hönnuðir vildu leggja ríkari áherslu á frjálst flæði innan verkefna og vildu ekki festa sig í ferli líkt og IDEO lagði upp með. Jafn- 
framt vildu hönnuðir síður einskorða aðferðir hönnunarhugsunar við lausn vandamála (e. problem-solving) sem peim fannst full mikil einföldun og kusu heldur hafa opnari nálgun á viðfangsefnin (Dorst, 2011). Eftir pví sem aðferðir hönnunar færðust inn á ný svið í starfsemi fyrirtækja par sem ekki var hefð fyrir virkri aðkomu hönnuða, kom einnig í meira mæli upp núningur í samstarfi hönnuða og stjórnenda fyrirtækja (Dorst, 2011; Lockwood, 2010; Liedtka, King og Bennett, 2013).

\subsection{Hringnum lokað}

Sú ferlavæðing sem lá til grundvallar í nálgun IDEO og annarra á hönnunarhugsun var nokkuð umdeild meðal hönnuða og var talin ganga gegn skapandi ferli peirra og innsæi (Cross, 2011). Í stað pess að hönnunarhugsun væri sveigjanleg aðferð sem hönnuðir beittu til að fá innlegg notenda í alls kyns vandamál væri hún orðin að fastmótuðu ferli sem verkfræðingar beittu til að leysa vandamál með áherslu á viðskiptalífið. Pótt pessi togstreita milli hönnunar og ferlavæðingar hafi ekki verið óyfirstíganleg, má segja að hún hafi engu að síður skapað jarðveginn fyrir nýja nálgun, par sem áherslan er ekki síður á sjálfbærni en nýsköpun. Hönnunarhugsun er samkvæmt pessu sjónarhorni tól til pess að takast á við samfélagslegar áskoranir á borð við bætta hráefnisnýtingu, fullnýtingu afurða, takmörkun á sóun, umhverfissjónarmið, og samkeppnishæfni ríkja (Hoo Na o.fl., 2017; Danska utanríkisráðuneytið, 2017). Meðal annars hafa rannsóknir á notkun aðferðanna innan samfélagslegra verkefna sýnt fram á mikilvægi pess að uppfæra gamla og úrelta stjórnsýsluferla sem endurspegla ekki tæknilega próun eða breyttar samfélagslegar áherslur nútímans (Liedtka, Salzman og Azer, 2017).

Á síðustu árum hefur verið mikil umræða um hvernig nýta megi aðferðir hönnunarhugsunar til að auka sjálfbærni og takmarka sóun og úrgang í hagkerfinu (Urbinati, Chiaroni og Chiesa, 2017). Í stað hins línulega hagkerfis (e. linear economy), sem byggir á að hráefni er nýtt til pess að framleiða fullunnar vörur sem á endanum verða úrgangur аð líftíma peirra loknum, kæmi „hringrásarhagkerfi“ (e. circular economy), sem byggir á endurhönnun allra ferla sem snúa að framleiðslu með pað að markmiði að takmarka sóun, draga úr mengun og nýta betur hráefni (Chesire, 2015; Webster, 2016). Hugmyndin sækir fyrirmynd sína til náttúrunnar og byggir á vistkerfum (e. ecosystems) hennar par sem allt er hluti hringrásar. Pannig er allt hráefni hluti af lokuðu kerfi par sem auðlindir og aðföng eru endurnýtt og haldið inni í hringiðu framleiðslu og notkunar sem er talið skapa aukið virði fyrir fyrirtæki yfir lengri tíma (Urbinati, Chiaroni og Chiesa, 2017; Lacy og Rutquist, 2015).

Hugmyndin byggir meðal annars á peim möguleikum sem hafa skapast í kjölfar tæknipróunar og upplýsingamiðlunar. Auðveldari samskipti einfalda nýtingu á öllu hráefni sem fellur til í framleiðslu, sem leiðir til takmörkunar úrgangs og eflingar á endurnýjanlegum orkugjöfum (Webster, 2016). Par er byggt á fyrri kenningum um „frá vöggu til vöggu“ hagkerfið (e. cradle-to-cradle) (McDonough og Brungaurt, 2002) og „bláa hagkerfið“ (e. blue economy) (Pauli, 2010). Pessi nálgun á hönnun í framleiðslu felur m.a. í sér að framleiðslutæki og ferli eru hönnuð og byggð upp á annan máta bæði til að hámarka nýtingu hráefnis og til að takmarka úrgang. Pá felur petta í sér endurhönnun á framleiðslutækjum og vélbúnaði pannig að byggingarefni framleiðslutækjanna sjálfra sé endurnýtanlegt (Webster, 2016).

Fáar rannsóknir hafa verið unnar hér á landi um beitingu á aðferðum hönnunarhugsunar innan íslensks atvinnulífs. Pær rannsóknir sem um er að ræða hafa pó helst tengst afmörkuðum verkefnum sem snúa að hámarksnýtingu hráefnis í takt við hugmyndafræði um hringrásarhagkerfið, til dæmis tækifærum til að bæta afurðanýtingu bænda í samhengi við ullarvinnslu (Helga Lára Halldórsdóttir, 2014; Sigrún Thorlacius, 2014). Einnig hafa verið gerðar rannsóknir á umfangi hönnunarstarfs í alpjóðlegu samhengi, en í samanburðarkönnun Nordic Design Resource (2018) kom fram að hlutfall fólks sem starfar við hönnun (e. design professionals) er 2,5\%. Рað hlutfall kann að virðast lágt en er pó pað 
hæsta á Norðurlöndum. Á móti kemur að hlutfall menntaðra hönnuða í pessum hópi er $62 \%$, sem er lægra en á öðrum Norðurlöndum að Finnlandi undanskildu. Við beinum sjónunum aftur á móti að nýtingu hönnunarhugsunar á Íslandi í fjölbreyttu samhengi, með eigindlegri rannsókn á mörgum mismunandi verkefnum sem unnin hafa verið hér á landi. Par er bæði um að ræða verkefni sem unnin hafa verið með sjálfbærni í forgrunni og verkefni par sem hönnunarhugsun var beitt á öðrum forsendum.

\section{Aðferðafræði}

Umfangsmesti páttur rannsóknarinnar fólst í eigindlegum viðtölum við einstaklinga með reynslu af beitingu hönnunarhugsunar og er fjallað um pann pátt í næstu premur undirköflum. Í kjölfar viðtalanna var unnin myndræn greining á heimildum og er fjallað um pann pátt í fjórða undirkaflanum.

\subsection{Framkvæmd viðtala}

Markmið viðtalanna sem byggt er á var að leita upplýsinga um reynslu og upplifun pátttakenda af notkun hönnunarhugsunar innan fyrirtækja og stofnana; pví var notast við eigindlegt rannsóknarsnið í formi hefðbundinna hálfopinna viðtala par sem byggt var á viðtalsramma sem ætlað var að veita ákveðinn grundvöll fyrir umræður um viðfangsefnið. Upphaflegur viðtalsrammi byggði á pekkingu rannsakenda á hönnunarhugsun og fræðilegum heimildum um viðfangsefnið. Rammanum var svo breytt lítillega eftir fyrstu tvö viðtöl rannsóknarinnar, byggt á peirri innsýn sem viðmælendur veittu um efnistökin, með pað að markmiði að styrkja forsendur rannsóknarinnar.

Viðtölin voru alla jafna á bilinu 50-70 mínútur og voru flest peirra tekin á vinnustað viðmælenda. Pó reyndist nauðsynlegt að taka prjú viðtöl í gegnum Skype, og eitt fór fram á kaffihúsi. Viðtölin voru í öllum tilvikum hljóðrituð, með leyfi viðmælenda. Unnin voru greiningarblöð fyrir og eftir viðtölin par sem leitast var við að leggja fram pær upplýsingar sem gætu aðstoðað við úrvinnslu efnisins. Hvert viðtal var svo afritað að fullu innan við viku frá viðtalinu.

\subsection{Val á viðmælendum}

Alls voru tekin viðtöl við fjórtán einstaklinga. Forsendur fyrir vali á viðmælendum voru að verkefni peirra væru unnin á Íslandi með notendamiðaða lausnapróun að markmiði. Ekki var gerð krafa um að viðmælendur skilgreindu verkefnin út frá hönnunarhugsun, heldur að peir hefðu nýtt sér minnsta kosti fjögur skref hönnunarhugsunar í próun og framkvæmd verkefna. Pví fól pað í sér nokkra rannsóknarvinnu að finna verkefni sem uppfylltu pessar forsendur. Upplýsingar um mögulega viðmælendur fengust úr umfjöllun um verkefni eða viðmælendur í birtu efni, úr fyrirlestrum, til dæmis í tengslum við Hönnunarmars, og að hluta til með snjóboltaaðferð par sem viðmælendur bentu á aðra sem höfðu unnið með svipuðum aðferðum.

Val á viðmælendum fór pví að hluta til fram samhliða rannsókninni sjálfri byggt á peim upplýsingum sem rannsóknin leiddi í ljós (Glaser, 1960). Reynt var að taka viðtöl við aðila fyrir hönd allra peirra verkefna sem upplýsingar fundust um. Fyrir nokkur verkefni fengust ekki viðmælendur, en pessir fjórtán viðmælendur standa pó fyrir mikinn meirihluta peirra verkefna sem rannsakendur vita af og uppfylla skilyrðin sem sett voru. Viðtölin fóru fram sumarið og haustið 2017, að undanskildu einu viðtali sem fór fram töluvert síðar, eða vorið 2019. Ástæða pess hve miklu síðar síðasta viðtalið fór fram var sú að ekki hafði fengist viðmælandi til pátttöku frá pví verkefni fyrr. Í pví viðtali komu fram gagnlegar upplýsingar sem hjálpuðu til við að varpa ljósi á viðfangsefnið og var pví ákveðið að bæta pví við rannsóknina, en pess gætt að greining á pví væri sett í samhengi við fyrri viðtöl. 
Tafla 1. Upplýsingar um viðmælendur, tilvísanir peirra í aðferðafræði, og nánari uppýsingar um stöðu og verkefni viðmælenda.

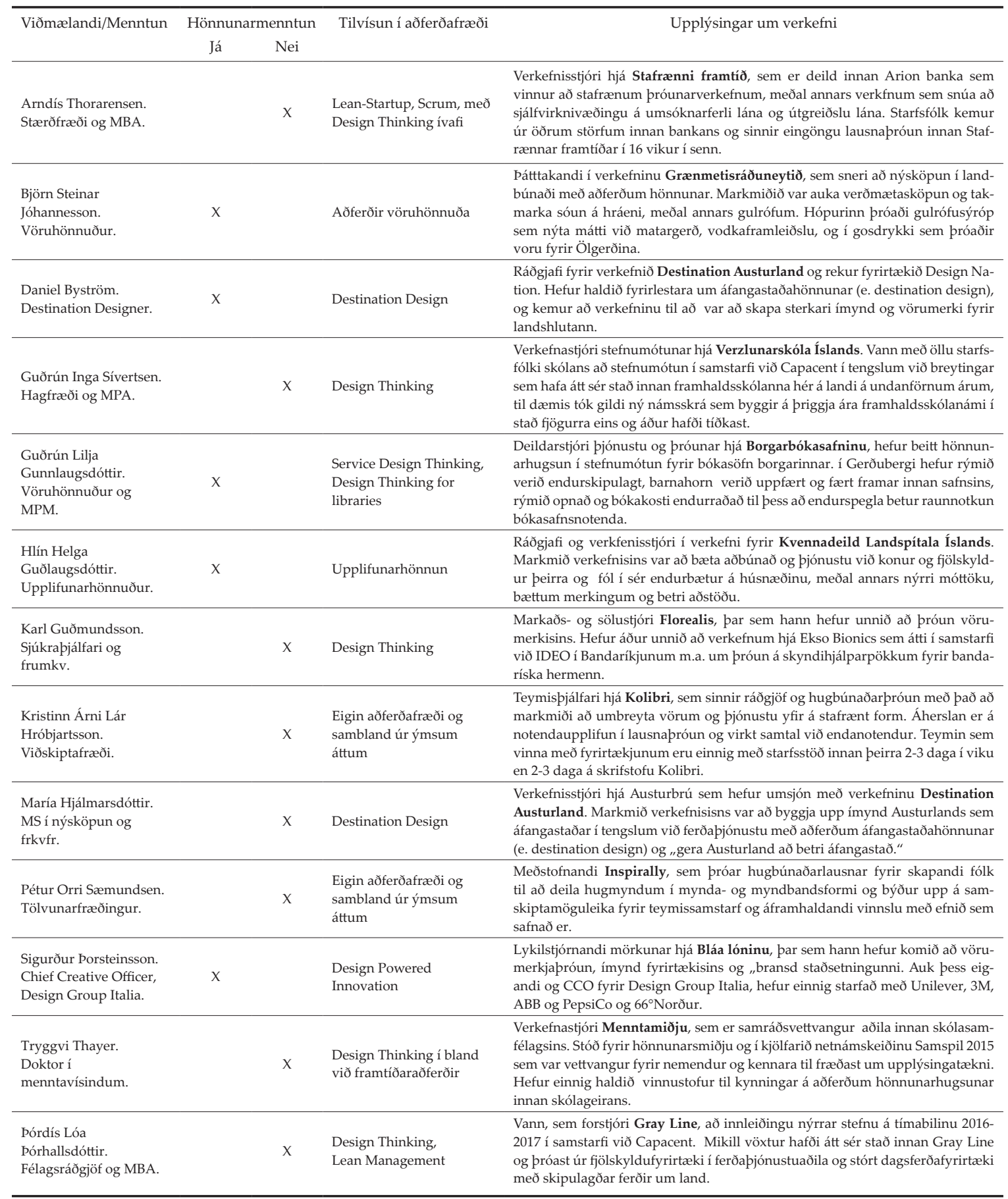

Par sem pau verkefni sem viðmælendur hafa komið að standa fyrir stóran hluta peirra verkefna sem uppfylla skilyrði til pátttöku í rannsókninni hefði purft að takmarka umfjöllunina töluvert til að sönn nafnleynd hefði ríkt. Рað á ekki síst við í ljósi pess að verkefnin eru fjölbreytt og eiginleikar verkefnanna móta aðferðir og nálgun sem beitt er. Viðmælendur voru spurðir hvort peir óskuðu nafnleyndar en enginn peirra gerði pað. Ekki er útilokað að einhverjir pættir í frásögn viðmælenda hefðu verið öðruvísi ef nafnleynd hefði verið heitið fyrirfram. Að metnum mögulegum takmörkunum af pví að viðmælendur hefðu hagað frásögn sinni öðru vísi undir nafnleynd á móti peim takmörkunum sem hefðu hlotist af pví að geta ekki fjallað um verkefnin sem viðmælendur höfðu komið að varð fyrir valinu að vinna ekki undir nafnleynd. 
Í töflu 1 er listi yfir viðmælendurna og eins og sést af töflunni var viðmælendahópur rannsóknarinnar nokkuð fjölbreyttur. Yngsti viðmælandinn var 26 ára gamall og sá elsti um fimmtugt, par af voru sex konur og átta karlar. Раð sem viðmælendurnir eiga sameiginlegt er hátt menntunarstig, pverfaglegur bakgrunnur og/eða reynsla af pátttöku í pverfaglegum verkefnum. Sex viðmælenda voru fagmenntaðir hönnuðir sem höfðu starfað á breiðu sviði hönnunar og jafnvel bætt við sig menntun á öðrum sviðum, og eru peir auðkenndir í öðrum dálki töflunnar. Aðrir voru með háskólamenntun á sviði frumkvöðlafræði, viðskiptafræði, sjúkrapjálfunar, fjölmiðlafræði, menntavísinda og framtíðarfræði, tölvunarfræði og hagfræði svo að nokkur dæmi séu nefnd. Í töflunni kemur einnig fram með hvaða hætti viðmælendum var tamast að vísa í aðferðafræðina sem notuð var. Sumir viðmælendur notuðu hugtakið „design thinking“ en aðrir ræddu almennt um ,aðferðir vöruhönnuða“, "destination design“, eða "lean management". Að endingu koma fram upplýsingar um pau verkefni sem viðmælendur höfðu tengst og rætt var um í viðtölunum.

\subsection{Greining viðtala}

Eftir að öll viðtöl rannsóknarinnar lágu fyrir í afriti voru pau kóðuð, pví næst var leitast við að greina lýsingar og frásagnir viðmælenda, og meginpemu dregin fram úr gögnunum með hefðbundinni pemagreiningu (Merriam, 2009). Fram komu tíu stærri pemu (samtal, valdefling, óvissa, togstreita, flækjustig, starfsandi, teymissamstarf, traust, smitáhrif, arðsemi), auk smærri efnispátta. Greiningu var svo haldið áfram í anda grundaðrar aðferðar (Glaser og Strauss, 1967), og ályktanir dregnar um mikilvægustu pætti sem móta upplifun viðmælenda af beitingu aðferðarinnar. Í peirri greiningu voru fjögur pemu sem vörpuðu sterkustu ljósi á ferli hönnunarhugsunar eins og henni hefur verið beitt af viðmælendum, sem og á pá sýn sem viðmælendur hafa á aðferðafræðinna. Til að halda afmörkun og stilla umfangi greinarinnar í hóf var áhersla lögð á pessi fjögur pemu og ekki fjallað sérstaklega um önnur. Pessi fjögur pemu eru samtal, valdefling, óvissa, og togstreita.

Í peirri greiningu og stöðuga samanburði (e. constant comparision) sem unninn var á viðtölunum sjálfum og heimildum um hönnunarhugsun komu enn fremur fram vísbendingar um að nálgun og upplifun viðmælenda mótaðist af peim mismunandi stefnum sem hafa einkennt hönnunarhugsun og próun hennar. Ákveðið var að vinna úr pessum vísbendingum í samræmi við hugmyndir Glaser um að ",allt sé gögn“ (Glaser, 2001:145), hvort sem pað eru viðtöl, skjöl, eða annað í umhverfi pess sem liggur að baki frásögn viðmælenda. Pví var farin sú leið að framkvæma myndræna greiningu á heimildum um hönnunarhugsun til að nálgast viðfangsefnið frá öðru sjónarhorni.

\subsection{Greining á heimildum}

Sú greiningaraðferð sem byggt var á við vinnslu inngangskaflanna um hönnunarhugsun og sögu hennar var hefðbundin heimildarýni (e. traditional literature review). Til að fá myndræna sýn á hvernig umfjöllun um hönnunarhugsun hefur próast, byggt á samlestri viðtalsgagna og peirra heimilda sem unnið hafði verið með í hefðbundnu heimildarýninni, var aftur á móti ákveðið að greina einnig fjölda birtra greina um efnið eftir lykilorðum (e. key words). Stuðst var við PubMed gagnagrunninn sem hefur verið nýttur til slíkrar greiningar af öðrum rannsakendum (t.d. Blaga, Vasilescu, og Chereches, 2018), og býður upp á ítarlega lykilorðaleit fyrir tímabilið sem er til skoðunar.

Pegar leitað var að fjöldatölum birtra greina með hjálp par til gerðs vefviðmóts (PubMed, 2017), kom í ljós mikil aukning í umfjöllun um hönnunarhugsun og aðferðir hönnunar á liðnum áratugum. Árið 2015 mátti finna nærri tvö púsund greinar sem innihalda orðin „design thinking“ samkvæmt grunninum, en til samanburðar birtust innan við prjú hundruð greinar á öllum áttunda áratugnum samkvæmt sömu heimild.

Hafa parf í huga að fjöldi birtra greina á öllum fræðasviðum hefur aukist til muna á pessu tímabili og pví er ekki rétt að draga of sterkar ályktanir af heildarbirtingum einvörðungu. Til að sú mikla aukning heildarfjölda greina trufli ekki greiningu er heppilegra, 
pegar hægt er, að skoða hlutfall greina innan tiltekins heildarmengis sem innihalda tiltekin lykilorð. Í pessu tilviki lá beint við að afmarka heildarmengið með orðunum „,design thinking." Með pví að skoða hlutfall greina innan pessa heildarmengis sem innihéldu tiltekin efnisorð til viðbótar var unnt að fá mynd af pví hvernig áherslur innan aðferðafræðinnar hafa próast. Niðurstöður pessarar greiningar eru settar fram í kafla 4.5 hér að neðan.

Greining á fjölda birtra ritrýndra greina um tiltekið efni er ekki endanlegur dómur um mikilvægi pess á hverjum tíma. Einungis er um að ræða vísbendingar sem túlka parf í samhengi við önnur gögn til að draga ályktanir og smíða kenningar sem byggja á gögnunum í anda grundaðrar aðferðar (Glaser og Strauss, 1967).

\section{Niðurstöður}

Hjá viðmælendum kom fram að hönnunarhugsun styður við samtal milli mismunandi aðila, bæði á pann hátt að miðla upplýsingum um hönnunarferlið og með pví að efla upplýsingaflæði almennt. Annar páttur sem viðmælendur sáu sem ótvíræðan kost við aðferðafræðina var valdefling, bæði peirra sem koma beint að verkefninu og með útvíkkun skilgreiningarinnar á hagsmunaaðilum. Priðji pátturinn sem áberandi var hjá viðmælendum var óvissa - annars vegar út frá hönnunarhugsun sem leið til að takast á við óvissu á jákvæðan hátt, en hins vegar í samhengi við óvissu um ferlið og endanlega niðurstöðu sem gat verið ópægileg fyrir hagsmunaaðila. Fjórði pátturinn sneri aftur á móti að togstreitu sem viðmælendur upplifðu í ferlinu vegna mismunandi áherslna og nálgunar. pegar pessir pættir, eða pemu, voru mátaðir við sögu hönnunarhugsunar, meðal annars með hjálp myndrænnar greiningar á heimildum, mátti sjá ákveðna samsvörun milli pessara pátta og tímabila í sögu hönnunarhugsunar. Pessi tímabil má líta á sem prjár bylgjur hönnunarhugsunar, sem móta mismunandi sjónarhorn gagnvart aðferðafræðinni.

\subsection{Samtal}

Fyrsta pemað, samtalið, snýr að pætti sem viðmælendur upplifðu sem stóran hluta af ferlinu að baki hönnunarhugsunar í verkefnum sínum, sem er opið samtal milli aðila verkefnisins. Samhljómur var meðal viðmælenda um að traust og virkt samtal væri grundvallarforsenda pess að verkefnin hlytu brautargengi sem rímar við grundvallaráherslur í umfjöllun um hönnunarhugsun (Kelley, 2005, 2016; Brown, 2009; Cross, 2011; van Reine, 2017; Rieple, 2016; Nixon, 2016). Í viðtölunum var áberandi að viðmælendur sáu petta sem einn af helstu kostum hönnunarhugsunar. Umhverfið og hraðar breytingar kölluðu á að fleiri ættu aðkomu að samtalinu, eins og Hlín Helga sagði: „Fyrir mér er petta eina leiðin, af pví að pað er ekkert hægt í dag að búa til, pað er enginn einn með lausn, pað er bara ekki pannig“. Björn Steinar taldi að áherslan á opið samtal og virka leit að aðilum sem geta búið yfir mikilvægri innsýn fyrir verkefni byggi á aðferðum hönnuða:

Ég held að styrkur hönnuða liggi kannski að einhverju leyti í pví að viðurkenna að við vitum ekki allt og að hika ekki við að leita aðstoðar, pannig að pá bara hendum við út öllum netum sem við höfum til að leita að fólki sem veit meira um pessi mál. (Björn)

Tryggvi fjallaði um mikilvægi pess að hafa fjölbreytni í hópum til að láta ólíkan hugtakaheim og reynslu tala saman. Að hans mati býr fjölbreytileikinn til ákveðna dýnamík sem leiðir til pess að nýjar hugmyndir koma fram. Í pví samhengi nefnir Tryggvi dæmi úr verkefnum innan Menntamiðju sem snúa að upplýsingatækni og starfspróun kennara. Par vinnur hann mikið með kennurum sem oft hafa takmarkaða pekkingu á tæknipróun og framtíðartæknilausnum. En með aukinni fjölbreytni innan hópanna fáist mismunandi sýn á viðfangsefnið, aðilar sem hafa annan reynslugrunn geti lesið eitthvað út úr lausnunum sem hóparnir setja fram sem aðrir hafa ekki séð: „Og pað er svona, að mínu mati, að thats where the magic happens, - í rauninni“. Parna er samhljómur við kenningar um hönnunar- 
hugsun og pað mikilvægi sem aðferðirnar leggja á opið og virkt samstarf (Kelley, 2016; Brown, 2009; Cross, 2011; Rieple, 2016).

Björn talaði á svipuðum nótum pegar hann fjallaði um ólík viðhorf gulrófubænda og hönnuðateymisins pegar hópurinn var að skoða mögulegt samstarfsverkefni. Aðspurður hvort hann hafi velt pví fyrir sér hvort einhverjar ástæður kunni að hafa legið baki pví að bændur hafa ekki vakið máls á peirri sóun sem ætti sér stað á landbúnaðarafurðum, svaraði hann:

Ég held að pað sé bara mismunandi hugsunarháttur. Ef pú ert alinn upp við að rækta rófur pá ræktar pú rófur en síðan pá, einmitt petta, að bjóða einhverjum sem að finnst rófur ekki einu sinni góðar að koma í heimsókn pá væntanlega er ég með einhvern nýjan vinkil á pað. (Björn)

Pað kom pó fram hjá viðmælendum að viss áskorun væri í pví falin að auðvelda pverfaglegt samtal milli ólíkra aðila. Hver deild á starfsstöðum viðmælenda pekkti til eigin verkefna og markmiða en hafði hvorki menntun né nægan skilning á verkefnum annarra deilda eða aðila til pess að geta átt auðvelt samstarf strax í upphafi. Viðmælendur röktu pennan skort á innsýn meðal annars til hefðbundinnar verkefnaskiptingar inni á vinnustöðum par sem skortur væri á virku samtali milli deilda og bentu jafnframt á að ekki væri næg áhersla lögð á hæfni í pverfaglegu samstarfi í menntakerfinu, m.a. með pví að veita nemendum kost á að læra grundvallaratriði annarra greina.

\subsection{Valdefling}

Upplifun viðmælenda á valdeflingu notenda, starfsmanna og annarra hagsmunaaðila var áberandi i viðtölunum. Pessar niðurstöður eru í takt við kenningar hönnunarhugsunar um áhrif pess að beita notendamiðaðri lausnapróun (Rieple, 2016; Lockwood, 2010). Í sumum tilvikum var valdeflingin meðvituð og hugsuð til að auka stuðning við verkefnin. Guðrún Inga fjallaði til dæmis um pað, hvernig við kynningu á nýjum verkferlum hafi hún vísað til pess að allir starfsmenn hafi haft tækifæri til að koma að próun verkefnisins og pví talaði hún um „niðurstöðurnar okkar":

Раð er svo gott að við fórum í stefnumótun og pað fengu allir að taka pátt sem vildu. Pannig að niðurstöðurnar eru niðurstöður okkar og út úr pessu kom að við ætlum að gera petta svona. ... Pú veist, petta eru ekki niðurstöður Capacent eða stjórnenda eða neitt svoleiðis. (Guðrún Inga)

Guðrún Lilja segir einnig frá hvernig hún notar tilvísun til sameiginlegrar ákvarðanatöku og aðkomu allra starfsmanna í stefnumótunarferlinu til pess að halda dampi í verkefnum og tryggja samræmi verkefna. Hún segir jafnframt að hún hafi séð miklar jákvæðar breytingar á viðhorfi starfsmanna til verkefna par sem peim finnist peir eiga hlutdeild í ákvörðunum. Hún telur að í pví samhengi hafi verið mikilvægt að leitað hafi verið sérstaklega til starfsmanna um að koma með eigin hugmyndir inn í ferlið. Рað hafi haft áhrif á hvernig starfsfólk sér og upplifir vinnuna sína og pau áhrif sem pað getur haft á próun vinnustaðarins.

Í öðrum tilvikum snýr valdeflingin að pví að gera notendur eða viðskiptavini sjálfstæða í framhaldi af verkefnunum. Kristinn fjallaði um pá áherslu Kolibri að valdefla samstarfsaðila sína pannig að fyrirtækin séu fær um að reka og próa áfram hugbúnaðarlausnirnar sem Kolibri vinnur fyrir pau eftir að samstarfinu lýkur:

Við reynum yfirleitt að vera með einn eða tvo forritara frá peim inni í okkar teymum pannig að pau læri af okkur bæði vinnuaðferðir og líka á vöruna ... svo viljum við bara „OK, nú erum við búin að koma ykkur á flug, nú getið pið tekið petta áfram“. (Kristinn Lár) 
Svipað var uppi á teningnum hjá Pórdísi Lóu en hún taldi að miklar breytingar hafi átt sér stað á starfsanda fyrirtækisins og að hann hafi eflst meðan á verkefninu stóð. Sameiginleg framtíðarsýn, bættur skilningur á hlutverki ólíkra deilda og pátttaka allra starfsamanna í verkefninu spili par stóran pátt. Fólk sjái störf sín í nýju ljósi og skilji betur tilgang verkefnanna. Pessari valdeflingu fylgdi ekki einungis aukin áhersla á fyrirframskilgreinda aðila verkefnisins, heldur leiddu verkefnin í sumum tilvikum af sér útvíkkun á mengi pessara aðila. Par vísaði Pórdís Lóa til dæmis til nýrra áherslna í samskiptum fyrirtækisins við söluaðila erlendis sem byggjast á pví sem hún kallaði „agenta-umhyggju“, par sem athyglinni var beint að pví hvernig hægt væri að bæta upplifun söluaðila af pví að eiga í samskiptum við fyrirtækið.

Pórdís Lóa fjallaði einnig um að í stefnumótunarvinnunni hjá Gray Line hafi hún séð hversu sterkar skoðanir starfsmenn fyrirtækisins hefðu á pjónustunni sem fyrirtækið veitir og gaman væri að sjá „ástríðuna blossa upp“. Par hafi m.a. verið gríðarleg ástríða fyrir pví hvernig ferðir væri boðið upp á og varðandi framtíðarsýn fyrirtækisins í tækni- og umhverfismálum. Pórdís Lóa sagði að sér hafi komið skemmtilega á óvart pessi ríka áhersla á umhverfismálin, stolt starfsmanna af landinu og frásagnargleðin, p.e. ánægja starfsmanna að sýna ferðamönnum fallega staði og að segja sögur af landi og pjóð.

Annað dæmi um útvíkkun á hagsmunahópi frá upphaflegri skilgreiningu kemur fram í lýsingu Maríu á próuninni innan verkefnisins Destination Austurland pegar athyglinni var beint í ríkari mæli ao íbúum svæðisins:

Рað sem kannski breyttist svolítið er að við sáum að pað var, pað yrði að vera fókus líka á íbúa og ekki bara ferðamenn, pannig að pað var svona ýmislegt í verkefninu sem snerist svo meira jafnvel að íbúum en ferðamönnum. Рað er kannski pað sem að gerðist svolítið fljótt, að við fundum раð аð heimamenn og íbúarnir skipta í rauninni meira máli, að peir séu í sátt og samlyndi við gesti og aðra sem koma hingað. (María)

Parna átti sér stað ákveðinn viðsnúningur par sem verkefnið átti í upphafi að snúast um Austurland sem áfangastað fyrir ferðamenn með áhersluá ferðapjónustuna. Daniel, sem kom að sama verkefni, nefndi hvernig pessi skilgreining víkkaði einnig með tilliti til pess hvaða svæði var undir, frá nærsvæðinu (e. local) til landsfjórðungsins (e. regional) og til landsins alls (e. national):

We need to ... try to think from the local perspective, to the regional, to the national perspective. We have everyone from Ferðamálastofa down to the local gas-station on the list of people. (Daniel)

Ólafur sagði að í pví verkefni sem hann kom að hafi pátttakendur upplifað skort á valdeflingu sem olli neikvæðri upplifun peirra á ferlinu. Samkvæmt Ólafi hafi starfsfólkið í pví tilviki ekki talið að nægilega víðtækt samráð hafi verið við alla starfsmenn sameinaðra stofnana og pað hafi ekki treyst ferlinu. Par hafi einnig haft áhrif langur aðdragandi og pólitískar umræður um stofnanirnar. Petta varpar ljósi á að ef ferlið veldur væntingum um valdeflingu getur haft mjög neikvæð áhrif ef mengi hagsmunaaðila er ekki nógu vítt.

Síðast en ekki síst má tengja pær hugmyndir um umhverfisáherslur sem fram komu hjá viðmælendum við valdeflingu og útvíkkun hagsmunaaðila á pann veg að náttúran og landið geti tilheyrt peim hópi í samræmi við kenningar Latour (2005). Áskoranir varðandi pessa pætti komu fram hjá Sigurði í tengslum við álag á Bláa lónið og stækkunarmöguleika, pví eins og hann komst að orði: „Ég meina við getum ekki hækkað verðið á lóninu til að hægja á fólki, pað er heldur ekki rétt leið, pað er alltaf fullt,“ en á endanum var ákveðið að fara í viðbætur sem voru minni en hugsanlega hefði verið hægt að gera og par með leita jafnvægis milli parfa viðskiptavina og umhverfis. Að lokum má nefna verkefni Grænmetisráðuneytisins sem sneru að pví að útvíkka pau verkefni par sem hönnunaraðferðum 
er beitt og valdefla bændur, en byggðu einnig mjög á hugmyndafræði um sjálfbærni og að lágmarka sóun, í samhengi við betri nýtingu á gulrófuframleiðslu.

\section{3 Óvissa}

Óvissan innan verkefnanna er í raun af tvennum toga. Annars vegar ríkir óvissa í umhverfi verkefnanna, bæði í nærumhverfi verkefnanna innan vinnustaðarins og í ytra umhverfi samfélags og tækni - hönnunarhugsun var að mati viðmælenda leið til að takast á við pessa óvissu á jákvæðan hátt. Hins vegar ríkir óvissa innan hönnunarhugsunarferlisins sjálfs par sem ekki er ljóst fyrirfram hvaða niðurstöður hvert skref leiðir af sér og hvaða áhrif pað hefur á endanlega lausn verkefnanna - pessi óvissa var að mati viðmælenda áskorun sem var að einhverju leyti neikvæður eiginleiki hönnunarhugsunar.

Sem dæmi um óvissu í ytra umhverfi vísaði Tryggvi til hraðrar próunar í tölvubúnaði frá spjaldtölvum yfir í snjallsímavæðingu, sem hefur leitt til pess að áherslur í kennslu hafa færst í auknum mæli á búnað nemendanna sjálfra. Pá séu kennarar að verða meðvitaðri um pennan breytingahraða en áður, en viti ekki hvernig eigi að bregðast við. „Pannig að petta getur breyst á nokkurra mánaða fresti pess vegna, bara eftir pví hvaða app nemendur í skólanum pínum fara að nota og pess háttar".

Pá fjölluðu viðmælendur einnig um áhrif verkefnanna á aðra starfsmenn starfseininganna sem ekki voru hluti af verkefnunum sjálfum. Spurningar á borð við hvort lausnin komi til með að leysa störf peirra af hólmi vakna upp, sem vekur vissan ótta hjá starfsfólki við nýjar lausnir. En starfsmenn voru jafnframt meðvitaðir um að fyrirtæki og pjónusta sé að breytast og breytingar séu nauðsynlegar par sem ný kynslóð kalli eftir nýjum lausnum. Meðal annars sagði Arndís: „Við vitum pað bara að pað eru kynslóðir sem eru að koma, pær vilja bara gera hlutina á netinu, vilja bara gera petta í símanum sínum. Pannig að annað hvort verður pú að breytast eða pú ert bara out. Рað vita petta allir“.

Kristinn fjallaði um óvissuna í nærumhverfi verkefnanna og taldi pað hjálpa til við að takast á við pá óvissu sem ríkir í hugbúnaðarpróun að flytja starfsstöð verkefnateymisins tímabundið inn á starfsstöð samstarfsaðila sinna:

Pað er svo mikil óvissa í hugbúnaðargerð af pví að oft erum við að tækla einhver vandamál sem að við höfum aldrei tæklað áður ... pað er verið að vinna á móti fullt af mismunandi kerfum, mismunandi kúltúr inni í fyrirtækjum og mismunandi prósess sem er inni í fyrirtækjum - pannig að við purfum að vita hratt hvort að við séum að gera eitthvað vitlaust og pá er langbest að vera hjá peim og sýna peim bara á skjánum pegar maður er búinn að gera eitthvað ... áđur en er búið að investa í fullt af tíma í að gera eitthvað allt annað en pað sem að beðið var um. (Kristinn Lár)

Einnig kom fram rík áhersla á pá miklu óvissu sem viðmælendur upplifðu innan hönnunarhugsunarferlisins sjálfs. Innan meirihluta verkefna viðmælenda gerðist pað аð grundvallarskilgreining á verkefninu sjálfu tók stórum breytingum. Oft má rekja pessar breytingar á viðfangsefninu til pess að pað er tekið til skoðunar út frá nýjum forsendum og aðrar spurningar lagðar til grundvallar fyrir verkefnið. Pétur lýsti pví hvernig umsnúningur varð innan hans verkefnis pegar notendasamtöl og prófanir sýndu að hugbúnaðurinn sem peir höfðu upphaflega próað hentaði ekki lausninni eins og hún leit út í endanlegri mynd.

Stjórnendur verkefnanna lýstu pví sömuleiðis að peir upplifðu ferlið sem töluvert flókið, bæði í tengslum við pað að ferlið er ekki línulegt og pannig væru pau stöðugt að færast milli ólíkra fasa innan verkefnisins, sem og að petta hafi verið mikið lærdómsferli fyrir pá stjórnendur sem ekki voru vanir að vinna verkefni með pessum hætti. Petta er í takt við niðurstöður rannsóknar Liedtka, King og Bennett (2013) sem sýndi að stjórnendur fyrirtækja eiga erfitt með að samræma hefðbundna viðskiptaferla og forskrift hönnunarhugsunar sem ólínulegs ferlis, p.e. að við próun verkefna megi fara aftur í fyrri skref. 
Hlín Helga taldi að rætur hönnunarhugsunar í áratugalangri próun á aðferðum faglærðra hönnuða styðji við frampróun verkefna pegar ferlið er svona „lífrænt“, p.e. pegar nýjum upplýsingum er leyft að hafa áhrif á næstu skref verkefna:

Petta er ekkert alveg ein lína - en engu að síður pá förum við í gegnum ólíka fasa og pú veist í einhverjum fasa pá bara uppgötvum við að pað vantar eitthvað og pess vegna er ég að segja „til baka“... En við vitum alltaf í hvaða fasa við erum, allir sem að eru að vinna að verkefninu, pað er mjög mikilvægt og рað er par sem að ferlið hjálpar alveg rosalega mikið. (Hlín Helga)

Viðmælendur voru sammála um að prátt fyrir pessa óvissu í ferlinu sjálfu varðandi útkomu verkefna pá veittu pær aðferðir sem hönnunarhugsun leggur upp með engu að síður góðan ramma fyrir framkvæmd peirra. Pá skipti máli að vera opinn fyrir breytingum á viðfangsefninu og hafa sveigjanleika til pess að bregðast við nýjum upplýsingum sem niðurstöður fyrri skrefa kunna að fela í sér. Jafnframt væri pað mikilvægt í frampróun peirra að setja alltaf eitthvað efni fram til pess að fá endurgjöf frá mögulegum notendum eða aðila sem pekkir til pannig að hægt sé að taka upplýstar ákvarðanir um framhaldið.

\subsection{Togstreita}

Fram kom í viðtölunum að viðmælendur upplifðu togstreitu af ólíkum toga innan verkefnanna. Togstreitan tengdist meðal annars takmörkuðum skilningi á hönnun í íslensku atvinnulífi, bæði innan ríkisstofnana og einkageirans. Einnig nefndu viðmælendur ólíka sýn peirra sem leiða verkefnin á hvað aðferðir hönnunarhugsunar fela í sér og hvernig aðferðirnar falla að peim ferlum sem fyrir eru innan fyrirtækisins eða stofnunarinnar sem um ræðir.

Flestir viðmælendur lýsa pví að pað hafi tekið nokkurn tíma að kynna nýjum samstarfsaðilum og starfsfólki hvað aðferðafræðin felur í sér og að oft hafi verið takmarkaður skilningur á hvernig „hönnun“ tengdist verkefnunum. Guðrún Lilja nefnir að „ég held að starfsfólkið skildi kannski ekkert fyrst hvað við vorum að reyna að gera, héldu bara að petta væri svona „skreytingarpjónusta“ en svo er pað búið að fatta smám saman að petta er kannski eitthvað meira!" María og Daníel nefna einnig að ákveðinn hópur hafi ekki haft trú á aðferðunum sem pau lögðu upp með í upphafi en pau sáu einnig ávinning af pví að taka inn gagnrýnar spurningar um ferlið og umræður um pað sem að lokum hafi styrkt verkefnið. Pá sé skortur á pví að aðilar innan atvinnulífsins sjái ávinning af pví að starfa með menntuðum hönnuðum og nefnir Björn að verkefnið Grænmetisráðuneytið hafi sérstaklega verið hugsað sem fordæmi fyrir fleiri verkefni sem unnin eru í samstarfi fyrirtækja og hönnuða.

Viðmælendur fóru ólíkar leiðir varðandi kynningu á pví í upphafi verkefna að verið væri að vinna eftir ákveðinni hugmyndafræði og pá var einnig ólíkt til hvaða heitis var vísað. Tryggvi nefnir að í ljósi pess hversu pröngur skilningur er á hugtakinu hönnun hér á landi hafi hann velt pví fyrir sér að sleppa pví að vísa til pess að hann vinni með aðferðir hönnunarhugsunar:

... petta hugtak, hönnun ... petta hefur mjög ákveðna merkingu. ... Petta er svolítið fast í hugum okkar Íslendinga að pað eru parna einhverjir „meðfæddir eiginleikar" sem að purfa að vera til staðar til pess að pú getir "framkvæmt list" eða verið „, аð hanna“... Pannig að ef ég nota petta hugtak pá reyni ég að útskýra hvað pað er sem að við erum að tala um pegar að við tölum um hönnun... (Tryggvi Thayer)

Karl tekur í sama streng og telur ekki endilega verkefnum til framgangs að nefna heiti aðferðarinnar pegar verkefnaáætlun er kynnt pó aðferðirnar byggist á henni. Innan Gray 
Line vísar Pórdís til ferlisins einvörðungu sem „stefnumótunar“ en ekki að aðferðirnar byggist á hönnunarhugsun.

Pá er einnig ólíkt hvernig peir viðmælendur sem hafa hönnunarmenntun og peir sem hafa annan bakgrunn líta á hlutverk sín og pær aðferðir sem peir beita innan verkefnanna. Peir viðmælendur sem ekki eru menntaðir hönnuðir hafa yfirleitt fastmótaða verkefnaáætlun par sem ákveðnu ferli er fylgt með föstum tímasetningum. Flestir sem vinna eftir pví fyrirkomulagi telja að önnur nálgun myndi ekki skila sama árangri innan peirra vinnustaða. Í verkefninu hjá Kvennadeildinni vann Hlín Helga sem sjálfstætt starfandi hönnuður í samstarfi við Líf Styrktarfélag og nýtti sér pann bakgrunn sem hönnunarnámið veitti henni og hennar sérsvið, upplifunarhönnun. Pá hefur hún einnig bakgrunn í ráðgjöf á sviði hönnunarhugsunar fyrir eitt stærsta ráđgjafarfyrirtækið hér á landi og hún dregur fram muninn á peim aðferðum sem hún beitir: „að er mikilvægt að gera greinarmun á aðferðum hönnuða, p.e. hvernig hönnuðir vinna, og hinu sem er "applied“ aðferðafræði hönnuða“, p.e. aðferða hönnunarhugsunar. Hlín vísar til pess að hönnuðir með sína menntun treysti á innsæi sitt í lausnapróun en í samstarfi við ólíka aðila og fyrirtæki sé nauðsynlegt að vinna eftir skýrum ramma. Sigurður gekk lengra og sagði ákveðinn hóp hönnuða vera ósátta við hvernig hönnunarhugsun hefur verið markaðssett af sumum verkfræðistofum og aðilum í fyrirtækjaráðgjöf:

[verkfræðistofur og ráðgjafar] ... hafa tekið yfir hönnunina gegnum ákveðna aðferðafræði ... Рað er allt svona linear. Hönnun er ekki linear hugsun - og parna er eitt af stóru vandamálunum! Раð er verið аð reyna að setja hönnun, með pví að búa til aðferðafræði, í linear hugsun pegar hún er pað ekki. (Sigurður)

Viðmælendur með hönnunarmenntun taka fram að peirra upplifun á pví að hugtakið hönnun sé pröngt skilgreint hér á landi hafi einnig átt við hönnunarsamfélagið sjálft lengi vel. Pað séu ekki nema tæplega tíu ár frá pví að notendamiðuð hönnun hafi rutt sér til rúms hér á landi og kom fram í máli Ólafs að hann próaði og kenndi fyrsta námskeiðið á pví sviði við Listaháskóla Íslands haustið 2010.

Í máli viðmælenda kom fram að ákveðin togstreita kom fram pegar unnið var innan rótgróinna kerfa sem gátu reynst hamlandi í framgangi verkefnanna par sem ekki var gert ráð fyrir nýrri nálgun innan starfseininganna, sérstaklega í stjórnsýsluumhverfinu. Î pví samhengi nefndi t.d. Guðrún Lilja áskoranir varðandi að sækja um fjármagn til nýrra útgjaldaliða á borð við upplifunarleikmynd og notendaprófanir par sem enginn bókhaldslykill var til sem féll að pessum páttum.

Sameining Menntamálastofnunar einkenndist af mikilli togstreitu par sem ekki ríkti einhugur um markmið sameiningarinnar. Að mati Ólafs liggja par ýmsir pættir að baki, meðal annars að starfsmenn hafi ekki skilið grundvallarforsendur aðferða hönnunarhugsunar, pær hafi ekki verið kynntar rétt í upphafi sem hafi leitt til pess að fólk upplifði pær sem „ameríska hugmyndarfræði“ sem tengdist peim á óskýran máta, pólitískur aðdragandi stofnunarinnar og að starfsmenn hafi ekki treyst ásetningi æðstu stjórnenda í sameiningunni.

Pá töldu viðmælendur að oft skorti á að hönnuðir og fyrirtæki nálguðust verkefni með sama skilning í upphafi, bæði hvað varðar innsýn á starfsaðferðir hvors annars, ferlið, hugtakanotkun og fleira. Settar voru fram vangaveltur um pað hvort pessa ólíku sýn og prönga skilning á hönnun mætti rekja til takmarkaðrar áherslu á skapandi greinar og pverfaglegar tengingar í almennri kennslu, sem og takmörkuðu samstarfi milli háskólastofnana. Viðmælendur höfðu einnig skynjað takmarkaðan skilning af hálfu hins opinbera á aðferðum hönnunar og upplifðu ekki að íslensk stjórnsýsla leggi virka áherslu á nýtingu á aðferðum hönnunar til að auka verðmætasköpun. 


\subsection{Bylgjur hönnunarhugsunar}

Í máli viðmælenda komu fram ólíkar áherslur og viðhorf gagnvart hönnunarhugsun. Sérstaklega átti petta við pegar kom að togstreitu milli hönnuða annars vegar og svo verkfræðistofa og ráðgjafa hins vegar, eins og Sigurður setti fram á skýran hátt. Petta mátti pó einnig greina í peim mismunandi áherslum sem komu fram hjá viðmælendum um einstaka pætti eða pemu. Til að fá annað sjónarhorn á pessar mismunandi áherslur var ákveðið að nýta myndræna greiningu á heimildum um hönnunarhugsun og kanna hvort mismunandi viðhorf eigi sér samsvörun í pví hvernig rætt hefur verið um aðferðina á mismunandi tímum. Eins og fram kemur í aðferðafræðikaflanum að ofan fór greiningin fram á pann hátt að skoðað var hlutfall heimilda í PubMed gagnagrunninum sem innihéldu mismunandi efnisorð, innan grunnmengis greina sem innihéldu efnisorðin „design thinking".

Hjá hluta viðmælenda kom fram mikil áhersla á að hafa opinn huga í lausnapróun og nýta samtalið á sveigjanlegan hátt sem innlegg í verkefnið. Pessir viðmælendur, sem voru flestir með formlega hönnunarmenntun, höfðu einnig tilhneigingu til að vísa til innsæis síns sem hönnuða í verkefnum. Рað rímar vel við fyrri alpjóðlega umfjöllun um ólíkar áherslur menntaðra iðnhönnuða og peirra sem tileinka sér aðferðir hönnunarhugsunar en hafa annan bakgrunn (Dorst, 2011; van Reine, 2017). Vegna náinnar tengingar pessarar nálgunar við iðnhönnun (e. industrial design) skoðuðum við hlutfall greina innan grunnmengisins sem innihéldu efnisorðið „industrial“. Niðurstöðuna má sjá í fyrstu línunni á mynd 2, sem er blálituð á myndinni.

Bláa línan, sem segja mætti að standi fyrir fyrstu bylgju hönnunarhugsunar, nær aftur til áttunda áratugarins. Henni tilheyrir umfjöllun par sem iðnhönnuðir og tengdir aðilar eru í leiðandi hlutverki og áhersla er lögð á að gera aðferðum hönnuða í rannsóknarvinnu og hugmyndapróun skil. Innan pessarar fyrstu bylgju próa hönnuðir nýtingu á aðferðum hönnunar á ólíkum sviðum (Rittel og Webber, 1973; Lawson, 1983; Bucciarelli, 1994; Cross, 2011; Rieple 2016). Pessi nálgun rímar einnig vel við umfjöllun um ólíkar áherslur menntaðra hönnuða og peirra sem tileinka sér aðferðir hönnunarhugsunar en hafa annan bakgrunn (Buchanan, 1992; Dorst, 2011; van Reine, 2017).

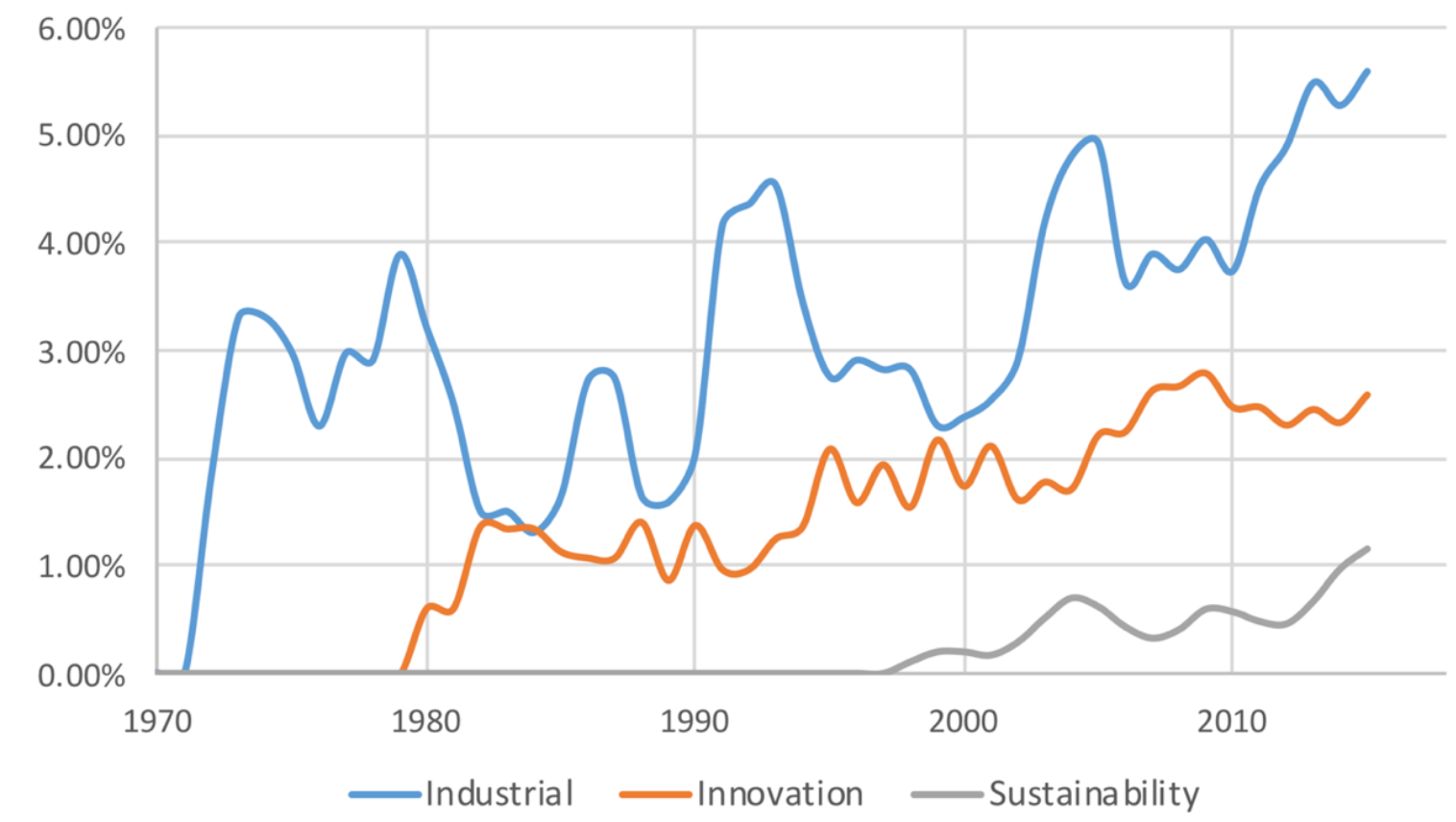

Mynd 2. Prjár bylgjur hönnunarhugsunar og tenging við leitarorð í heimildum 
Annar hópur viðmælenda hafði tileinkað sér aðferðir hönnunarhugsunar en var ekki með formlega hönnunarmenntun, heldur annan bakgrunn svo sem viðskiptafræði eða kennaramenntun. Pessir viðmælendur höfðu ríkari tilhneigingu til pess að vinna með fasta tímaáætlun fyrir verkefnin sem var engu að síður aðlöguð ef skref aðferðannar kröfðust pess. Í fræðilegri umfjöllun er pessi nálgun gjarna nátengd umræðu um hönnunarhugsun sem drifkraft nýsköpunar (e. innovation) frekar en tilvísun til rannsóknaraðferða hönnuða (Tonkinwise, 2011). Áherslan á nýsköpun endurspeglast í ríkri meðvitund viðmælenda um óvissu og hvernig á að bregðast við henni. Upplifun viðmælenda var að aðferðirnar veittu peim góðan ramma til að takast á við pær fjölpættu áskoranir og óvissu sem bjuggu í pessum ólíku verkefnum og hafi hjálpað peim að endurskilgreina viðfangsefni sitt á pann máta að lausnin hentaði hinu raunverulega vandamáli, sem gjarnan sýndi sig ekki fyrr en að lokinni nánari djúpskoðun í upphafi verkefnisins. Pví ákváðum við að kanna hlutfall greina innan grunnmengisins sem innihéldu orðið „innovation“ og má sjá niðurstöðuna á annarri línunni á mynd 2, sem er appelsínugul og má nefna aðra bylgju hönnunarhugsunar.

Pessi bylgja nær aftur til níunda áratugarins, pegar áherslan beinist í auknum mæli að nýsköpun og í kjölfarið er í auknum mæli farið að líta á aðferðir hönnunarhugsunar sem mótað ferli fyrir fyrirtæki og stofnanir til að ýta undir nýsköpun. Petta viðhorf á sér hliðstæðu í peirri alpjóðlegu próun að skoða hönnun innan óhefðbundnari verkefna en áður, svo sem hönnun á pjónustu, upplifun, ferlum og fleiru og sem að hluta til var drifin áfram af verkfræðingum frekar en menntuðum hönnuðum (Bucciarelli, 1988, 1994; Kelley, 2005, 2016; Verganti, 2009). Par er lögð rík áhersla á að hönnunarhugsun nýtist atvinnulífinu til að ýta undir nýsköpun innan fyrirtækja og sköpunarkraft starfsmanna til að bæta verðmætasköpun.

Priðja viðhorfið sem ákveðið var að kanna nánar með myndrænni greiningu á heimildum spratt af áherslum sumra viðmælenda á hönnunarhugsun sem aðferð til að styðja við sjálfbærni (e. „sustainability“). Greina mátti ákveðið samhengi á milli sjálfbærniáherslu og pemans um valdeflingu í umræðum viðmælenda um jákvæð áhrif aðferðarinnar á vinnustaðamenningu og starfsanda. Enn fremur endurspeglaðist pessi nálgun í notkun hönnunarhugsunar við að endurhanna ferla sem snúa að framleiðslu með pví markmiði að takmarka sóun, draga úr mengun og nýta betur hráefni. Hlutfall greina innan grunnmenginsins sem innihalda orðið „sustainability“má sjá á grárri línu á mynd 2.

Pessi priðja bylgja hönnunarhugsunar einkennist af sífellt breiðari notkun á aðferðum hönnunar í samfélaginu, ásamt áherslum á sjálfbærni og hugmyndum um hringrásarhagkerfi (Chesire, 2015; Lacy og Rutqvist, 2015; Webster, 2016). Pví fylgir aukin meðvitund innan fyrirtækja og stofnana um samfélagslega ábyrgð, auk pess sem samkeppnishæfni og sjálfbærni pjóða er meira áberandi. Samhliða eykst áhersla opinberra aðila á mikilvægi nýtingar aðferða hönnunar til nýsköpunar og verðmætaaukningar (Lockwood, 2010; Liedtka, Salzman og Azer, 2017; Martin, 2009). Viðmælendur sem fella má undir pessa bylgju unnu gjarna að verkefnum sínum með utanaðkomandi ráðgjöfum sem höfðu skýrt skilgreinda verkefnaáætlun með föstum tímasetningum sem sjaldan var vikið frá við lausnapróun. Viðmælendur pessir töldu jafnframt að slík nálgun á verkefnin væri lykilpáttur fyrir framgangi peirra innan starfseininganna.

Pessar prjár bylgjur hönnunarhugsunar hafa ekki rutt hver annarri úr vegi - eins og sjá má af myndinni ganga einstakar bylgjur ekki niður heldur er áframhaldandi töluverð próun í fræðilegri umfjöllun innan hverrar og einnar peirra. Að sama skapi geta einstakar rannsóknir eða einstök verkefni sem byggja á hönnunarhugsun sótt innblástur til fleiri en einnar bylgju. Pau mynstur sem sjást í fræðilegri umfjöllun eru í takt við pað sem fram kom hjá viðmælendum um framkvæmd verkefna sem byggja á aðferðafræðinni. Pannig hafa hönnuðirnir sem voru pungamiðjan í fyrstu bylgjunni haldið áfram að taka pátt í verkefnum sem byggja á hönnunarhugsun allt til dagsins í dag. Sú verkfræðilega áhersla 
á hönnunarhugsun í nýsköpun og vaxtastefnu fyrirtækja sem einkennir aðra bylgjuna er að sama skapi einnig áberandi prátt fyrir að sjálfbærniáherslur priðju bylgjunnar tvinnist í sífellt auknum mæli saman við nýsköpunaráherslur.

pegar pau pemu sem fram komu við greiningu á viðtölum voru mátuð við bylgjur hönnunarhugsunar eins og pær birtast í myndrænu greiningunni, komu fram ýmsar samsvaranir, sumar mjög lauslegar en aðrar voru skýrari. аð pema sem snýr að samtalinu markaðist af áherslu á að útvíkka hlutverk hönnunar yfir í stærri hóp, og var áberandi hjá peim viðmælendum sem höfðu hönnunarbakgrunn og féllu að pví leyti á vissan hátt að fyrstu bylgjunni. Рemað sem snýr að óvissunni átti sér mjög skýra hliðstæðu í peim áherslum á nýsköpun sem fylgja annarri bylgjunni, enda er par athyglinni beint að peirri óvissu sem fylgir nýsköpunarverkefnum og hvernig hægt sé að bregðast við henni. Í síðasta lagi kom fram ákveðin samsvörun milli pemans um valdeflingu og áherslum priðju bylgjunnar á sjálfbærni, en sú samsvörun kom sérstaklega fram í samhengi við útvíkkun á mengi hagsmunahópa og aukna athygli að umhverfi, landi og náttúru, í samræmi við kenningar Latour (2005). Að endingu eru pessar bylgjur í samræmi við pað pema sem tengist togstreitu, par sem ekki er um að ræða að tilteknar bylgjur hafi rutt öðrum úr vegi, heldur eru pær við lýði á sama stað og stund sem getur valdið núningi pegar einstaklingar með mismunandi bakgrunn og viðhorf setja verkefni sín í samhengi við aðferðafræðina.

Pessar prjár bylgjur eru ekki algild flokkun heldur aðeins ein kenningarleg nálgun og háð endurskoðun eftir pví sem ný gögn koma fram. Aftur á móti hjálpa pær til við að skilja og staðsetja pau verkefni par sem hönnunarhugsun hefur verið beitt, bæði á Íslandi og erlendis. Að sama skapi auðveldar pessi rammi mat á styrkleikum og áskorunum hönnunarhugsunar og varpar ljósi á mögulega próun hennar í framtíðinni.

\section{Umræður og lokaorð}

Í máli viðmælenda sem rætt var við í pessari rannsókn mátti greina pætti sem fjallað hefur verið um í erlendum skrifum um hönnunarhugsun, svo sem skilning á pörfum notenda, sveigjanleika og skapandi lausnir. Pessi ávinningur á sér samsvörun í hugmyndunum um hluttekningu og hugmyndun sem fram koma í pví fimm prepa ferli sem Kelley (2016) setti fram um hönnunarhugsun og almennt má segja að niðurstöðurnar séu í góðu samræmi við pá mynd af hönnunarhugsun.

Í rannsókninni var lagt upp með eftirfarandi rannsóknarspurningu: „Hvernig er hönnunarhugsun beitt við mismunandi aðstæður á Íslandi, og hvernig fellur beiting aðferðarinnar á Íslandi að straumum og stefnum á alpjóðlegum vettvangi. “ Í viðtölunum komu í ljós sameiginleg pemu sem einkenndu nálgun og áherslu viðmælenda í beitingu aðferðarinnar. Flest pau verkefni sem rætt var um við viðmælendur teljast hafa heppnast vel og voru kostir hönnunarhugsunar í forgrunni pegar kom að pví hvernig aðferðafræðin pótti styðja við samtal ólíkra hópa og stuðla að valdeflingu. Pó er rétt að geta pess að ekki póttu öll verkefnin hafa tekist jafnvel að mati viðmælenda. Par sem hönnunarhugsun pótti síður hafa leitt til ávinnings var pað rakið til pess að samtali og sérstaklega valdeflingu var ábótavant, par sem innlegg frá tilteknum hópum í ferlið jók á tilfinningu annarra hópa um að peir hafi ekki haft sambærileg tækifæri til innleggs. Að einhverju leyti má einnig rekja vandkvæðin til óvissu um ferlið og togstreitu um markmið og inntak.

Verkefnin voru unnin við töluvert mismunandi aðstæður, en höfundar greindu pó ekki sérstök mynstur í pví hvernig pessar ytri aðstæðu hefðu áhrif á pað hvernig hönnunarhugsun var beitt. Aftur á móti mátti greina að viðhorf og bakgrunnur peirra aðila sem leiddu verkefnin hefðu áhrif á beitingu aðferðarinnar og áherslur. Par mátti sjá ákveðna samsvörun við pær bylgjur hönnunarhugsunar sem höfundar hafa dregið fram. Viðmælendur með formlegan hönnunarbakgrunn, sem samsvara mætti fyrstu bylgjunni, voru líklegir til að leggja áherslu á hlutverk hönnunarhugsunar í draga fram mismunandi upplýsingar og frá ólíkum aðilum sem tengdust verkefnunum. Í peim tilvikum var ekki endi- 
lega um fastar tímaáætlanir að ræða heldur voru aðferðirnar notaðar lauslega og mótuðust eftir pví sem verkefnum miðaði áfram. Slík nálgun á mesta skírskotun við pemað um samtalið og valdeflingum, en í minna mæli við pemað um óvissuna.

Aðra bylgjuna mætti tengja við viðmælendur sem ekki hafa formlega hönnunarbakgrunn en hafa tileinkað sér aðferðina til viðbótar við aðra menntun. Hjá peim mátti greina áherslu á notkun aðferðarinnar til að takast á við og eyða óvissu í nýsköpunarferlum. Í peim tilvikum var frekar um fastmótaðar tímaáætlanir að ræða og skýrari ferla. Hjá einstökum viðmælendum mátti pó oft sjá meira en eina nálgun, sem er í samræmi við að bylgjurnar hafa ekki ýtt hver annarri til hliðar, heldur byggt hver ofan á aðra. Að pessu leyti er skýrt að peir pættir sem einkenna beitingu hönnunarhugsunar á alpjóðavettvangi virðast einnig hafa áhrif á Íslandi.

Pegar kemur að pví að meta orsakir óvissu og togstreitu er einnig áhugavert að velta fyrir sér að hve miklu leyti pær eru alpjóðlegar og að hve miklu leyti pær eru staðbundnar. Ósætti hönnuða hefur komið fram í erlendum rannsóknum, svo sem hjá Walters (2011), en einnig kom fram pað viðhorf að lítil meðvitund um aðferðir hönnunar á Íslandi hafi áhrif. Eins og fram kom að ofan gefa gögn pó ekki til kynna að Ísland skeri sig úr á afgerandi máta hvað pað varðar, par sem hlutfall fólks sem starfar við hönnun (e. design professionals) er 2,5\% af vinnuaflinu, sem er pað hæsta á Norðurlöndum (Nordic Design Resource 2018). Á móti kemur að hlutfall peirra úr pessum hópi sem hefur formlega hönnunarmenntun er lægra en á öðrum Norðurlöndum að Finnlandi undanskildu, eða 62\%.

Pessi rannsókn er innlegg í aukinn skilning á hönnunarhugsun, og hafa verið sett fram tiltekin mynstur og ályktanir sem dregnar voru af greiningu á viðtölum og heimildum. Par sem pau mynstur sem hér eru sett fram voru ekki komin fram pegar viðtöl voru tekin, voru pau eðli málsins samkvæmt ekki borin undir viðmælendur og pví liggur afstaða viðmælenda til peirra ekki fyrir. Petta er að hluta til eðlislægur eiginleiki rannsókna sem snúa að kenningasmíð (e. theory building) frekar en kenningaprófunum (e. theory testing), en varpar ljósi á að ákjósanlegt væri að fylgja rannsókninni eftir og sannreyna pessi mynstur frekar, hvort sem er með eigindlegum eða megindlegum aðferðum.

Раð væri auk pess æskilegt að gera kerfisbundnari rannsókn á hlutverki hönnunar í próunarverkefnum á Íslandi. Pótt pessi rannsókn sé ítarlegasta viðtalarannsókn á notkun hönnunarhugsunar hér á landi sem höfundum er kunnugt um, var ekki lagt skipulagt mat á pað við leit að verkefnum hversu stórt hlutfall slíkra verkefna hefði fundist. Megindleg rannsókn sem innihéldi slíkt mat væri gagnleg viðbót við pekkingu á hönnunarhugsun. Par væri áhugavert viðfangsefni að skoða með hvaða hætti fyrirtæki telja sig nýta sér hönnun og aðferðir hönnunar eða hönnunarhugsunar í starfsemi sinni, viðhorf til mikilvægis hönnunar og hvort virk notkun á aðferðum hönnunar skili sér í fjárhagslegum ávinningi fyrir fyrirtæki og aukinni verðmætasköpun. Pá væri áhugavert að gera rannsókn á pví hvernig stórfyrirtæki starfa að nýsköpun í dag og að hve miklu leyti peirra aðferðir eru í samræmi við eða frábrugðnar aðferðum hönnunarhugsunar.

Рað er von höfunda að sú nálgun sem hér hefur verið sett fram verði páttur í að auka skilning og áframhaldandi rannsóknir á aðferðum hönnunarhugsunar hér á landi. Prátt fyrir að notkun hönnunar og meðvitund um hana séu að aukast eru ýmis tækifæri til að nýta hana frekar við verðmætasköpun á breiðum vettvangi, bæði innan íslenskrar stjórnsýslu og á vettvangi atvinnulífsins. Ekki síst er pað mikilvægt í ljósi peirrar áherslu sem lögð er á slíka notkun í nágrannalöndum, og sem líklegt er að aukist frekar á næstu árum. 


\section{Heimildir}

Atvinnuvega- og nýsköpunarráđuneyti og Mennta- og menningarmálaráðuneyti (2014). Hönnunarstefna 20142017. Hönnun sem drifkraftur til framtíðar. http://www.honnunarmidstod.is/media/PDF/honnunarstefna.pdf

Berkowitz, M. (1987). Product shape as a design innovation strategy. Journal of Product Innovation Management, 4(4), 274-283.

Blaga, O. M., Vasilescu, L., \& Chereches, R. M. (2018). Use and effectiveness of behavioural economics in interventions for lifestyle risk factors of non-communicable diseases: a systematic review with policy implications. Perspectives in public health, 138(2), 100-110.

Brown, T. (2009). Change by Design: How design thinking transforms organizations and inspires innovation. New York: Harper Collins.

Bucciarelli, L. L. (1988). An ethnographic perspective on engineering design. Design studies, 9(3), 159-168.

Bucciarelly, L. (1994). Designing Engineers. Cambridge, Massachusetts: The MIT Press.

Buchanan, R. (1992). Wicked Problems in Design Thinking. Design Issues, 8(2), 5-21.

Chesire, I. (2015). Forewords. Waste to Wealth. The Circular Economy Advantage. Basingstoke: Palgrave Macmillan, $x$-xi.

Cooper, R., Junginger, S. og Lockwood, T. (2010). Design thinking and Design Management: A Research Practice Perspective. Í Lockwood, T. (ritstjóri), Design Thinking: Integrating Innovation, Customer Experience, and Brand Value (bls. 57-64). New York: Allworth Press.

Cross, N. (2011). Design Thinking. Understanding how Designers Think and Work. London: Bloomsbury Academic.

Dam, R. og Siang, T. (2017). 5 Stages in the Design Thinking Process. Interaction Design Foundation. Sótt af: https:// www.interaction-design.org/literature/article/5-stages-in-the-design-thinking-process

Danska utanríkisráðuneytið (2017). Competitive through Danish Design. Invest in Denmark. Sótt af http:// www.investindk.com/Clusters/Design

Dorst, K. (2011). The core of 'design thinking' and its application. Design Studies, 32(6), 521-532.

Framkvæmdastjórn Evrópusambandsins (2012). Design for Growth and Prosperity. Report and Recommendations of the European Leadership Board. European Design Innovation Innitiative. Helsinki: Unigrafia. Sótt af: https://www.sztnh.gov.hu/sites/default/files/design-for-growth-and-prosperity-report_en.pdf

Framkvæmdastjórn Evrópusambandsins (2013). Implementing an Action Plan for Design-Driven Innovation. Sótt af: http://ec.europa.eu/DocsRoom/documents/13203/attachments/1/translations

Framkvæmdastjórn Evrópusambandsins (2016). Design for Enterprises. A tool for SMEs development. Sótt af: http://www.designforenterprises.eu/

Glaser, B. G. (1965). The constant comparative method of qualitative analysis. Social problems, 12(4), 436-445.

Glaser, B. G. (2001). The Grounded Theory Perspective: Conceptualization Contrasted with Description. Mill Valley, Ca.: Sociology Press.

Glaser, B. G., og Strauss, A. L. (1967). The Discovery of Grounded Theory: strategies for qualititative research. Bern: Huber.

Helga Lára Halldórsdóttir (2014). Er íslenska ullin vanmetin auðlind?: Tækifæri í breyttri framleiðslu. BA-ritgerð við Listaháskóla Íslands.

Hoo Na, J., Choi, Y., Walters, A., Lam, B., Green, S. (2017). Creating a Tool for Measuring the Social Value of Design. The Design Journal, 20(sup1), 1662-1672.

Huppatz, D.J. (2015). Revisiting Herbert Simon's „Science of Design“. Design Issues, 31(2), 29-40.

Kelley, T. (2016). The Art of Innovation. Lessons in Creativity from IDEO, America's Leading Design Firm. London: Profile Books.

Kelley, T. (2005). The Ten Faces of Innovation. New York: Doubleday.

Kotler, P., og Alexander Rath, G. (1984). Design: A powerful but neglected strategic tool. Journal of business strategy, 5(2), 16-21.

Latour, B. (2005). Reassembling the social: An introduction to actor-network-theory. Oxford university press.

Lacy, P. og Rutqvist, J. (2015). Waste to Wealth. The Circular Economy Advantage. Basingstoke: Palgrave Macmillan.

Lawson, B. (1983). How designers think. London: Butterworth Architecture.

Liedtka, J., King, A. og Bennett, K. (2013). Solving Problems with Design Thinking. 10 Stories of What Works. New York: Columbia University Press.

Liedtka, J., Salzman, R. og Azer, D. (2017). Design Thinking for the Greater Good. Innovation in the social sector. New York: Columbia University Press.

Lockwood, T. (2010). Design Thinking: Integrating Innovation, Customer Experience, and Brand Value. New York: Allworth Press.

Martin, R. (2009). The Design of Business. Why Design Thinking is the Next Competitive Advantage. Boston: Harvard Business Press.

McDonough, W. og Brungaurt, M. (2002). Cradle to Cradle. Remaking the Way We Make Things. New York: North Point Press.

Merriam, S. B. (2009). Qualitative research: A guide to design and implementation. San Fransisco: John Wiley \& Sons. 
Nixon, N. (2016). Strategic Design Thinking. Innovation in Products, Services, Experiences, and Beyond. New York: Bloomsbury Publishing.

Nordic Design Resource (2018). Nordic Design Resource Country Profile. Sótt af: http://nordicdesignresource. $\mathrm{com} /$

Pauli, G. (2010). The Blue Economy: 10 Years, 100 Innovations, 100 Million Jobs. Taos: Paradigm Publication.

PubMed (2017). Medline trend: automated yearly statistics of PubMed results for any query. Sótt af: http://dan. corlan.net/medline-trend.html

Rieple, A. (2016). Theoretical Context for Strategic Design. Í Nixon, N. (ritstjóri), Strategic Design Thinking. Innovation in Products, Services, Experiences, and Beyond (bls. 3-21). New York: Bloomsbury Publishing.

Rittel, H. \& Webber, M. (1973). Dilemmas in a General Theory of Planning. Policy Sciences, 4(2), 155-169.

Roy, Robin (1993). Case studies of creativity in innovative product development. Design Studies, 14(4), $423-443$.

Sigrún Thorlacius (2014). Óplægður akur : samvinna hönnuða og framleiðenda. Óútgefin BA-ritgerð við Listaháskóla Íslands. Sótt af: http://hdl.handle.net/1946/22186

Simon, H. (1969). The Sciences of the Artificial. Cambridge: MIT Press.

Tonkinwise, C. (2011). A taste for practices: Unrepressing style in design thinking. Design Studies. 32(6), 533545.

van Reine, P. (2017). The culture of design thinking for innovation. Journal of Innovation Management. 5(2), 5680.

Verganti, R. (2009). Design-Driven Innovation. Changing the Rules of Competition and Radically Innovating What Things Mean. Boston, MA: Harvard Business Press.

Verganti, R. (2016). Overcrowded. Designing Meaningful Products in a World Awash with Ideas. Cambridge, MA: Massachusetts Institute of Technology.

Urbinati, A., Chiaroni, D., \& Chiesa, V. (2017). Towards a new taxonomy of circular economy business models. Journal of Cleaner Production, 168, 487-498.

Walters, H. (2011). “Design Thinking” Isn't a Miracle Cure, but Here's How It Helps. CO.DESIGN. Fast Company Inc. Sótt af: https://www.fastcodesign.com/1663480/design-thinking-isnt-a-miracle-cure-but-hereshow-it-helps

Webster, K. (2016). The Circular Economy: A Wealth of Flows. London: Ellen MacArthur Foundation Publishing.

Wilcox, S. (2016). Framing the Problem: Design Research. Í Nixon, N. (ritstjóri), Strategic Design Thinking. Innovation in Products, Services, Experiences, and Beyond (bls. 65-90). New York: Bloomsbury Publishing. 